\title{
Earnings Comparability and Firm-Specific Stock Price
}

\section{Crash Risk}

\author{
Ruixue Du \\ School of Business and Economics, University of Wisconsin Stevens Point \\ Wisconsin, United States
}

Shuo Li

College of Business and Economics, Western Washington University Washington, United States

Ling Tuo (Correspondence author)

College of Management, Lawrence Technological University

Michigan, United States

E-mail:1tuo@ltu.edu

Yu (Tony) Zhang

College of Management, Lawrence Technological University

Michigan, United States

Received: August 10, 2018 Accepted: September 4, 2018 Published: September 16, 2018

doi:10.5296/ijafr.v8i3.13659

URL: https://doi.org/10.5296/ijafr.v8i3.13659

\begin{abstract}
This study examines the association between earnings comparability and firm-specific stock price crash risk. Using a large sample of 33,696 firm-year observations from the U.S. public
\end{abstract}




\section{$\triangle$ Macrothink}

International Journal of Accounting and Financial Reporting

ISSN 2162-3082

2018, Vol. 8, No. 3

firms, we find a positive association between comparability and future stock price crash risk. This finding is consistent with the notion that corporate managers do not have much incentive to release firm-specific information (especially bad news), as long as their firms' financial statements are comparable to those of the industry peers. We further show that the positive association between earnings comparability and future crash risk is attenuated for firms with strong external monitoring (i.e., high analyst coverage, high institutional ownership, and high audit quality) and firms with low information asymmetry (i.e., low probability of informed trading). Our results are robust to (1) controlling for other important earnings attributes (e.g., conditional conservatism and income smoothing) that are associated with crash risk, (2) conducting change analyses, and (3) using alternative measures of earnings comparability. Our findings have an important implication that earnings comparability does not always result in favorable capital market outcomes.

Keywords: Earnings comparability, Stock price crash risk, External monitoring, Information asymmetry, Agency theory, Earnings attributes

\section{Introduction}

Stock price crash risk, a third moment of stock return distributions capturing extreme downside risk (Note 1), has become a critical issue for investors, regulators, practitioners, and researchers. Under the theoretical framework of Jin and Myers (2006), corporate managers have incentives to withhold firm-specific bad news from public disclosure for an extended period, resulting in severe overvaluation of the firm's price. However, once the accumulated bad news reaches a certain tipping point, all bad news is suddenly released at once, leading to a stock price crash. It has been well documented in the prior studies that certain factors can predict future stock price crash risk, such as financial reporting opacity, equity-based compensation, corporate tax avoidance, conditional accounting conservatism, and institutional ownership (Hutton, Marcus, and Tehranian, 2009; Kim, Li and Zhang, 2011a, 2011b; Kim and Zhang, 2016; Callen and Fang, 2013). In this paper, we extend this line of research by investigating the association between financial statement comparability and future stock price crash risk.

Earnings comparability is an important objective of financial accounting because investing and lending decisions cannot be made rationally in the absence of comparative information (FASB 1980 Concepts Statements No. 2). An individual firm's earnings are shaped by both firm-specific and industry-specific factors that could also have influence on the firms within the same industry. Cognitively, it is difficult for information users to assess information signals that are unique to a firm and accordingly individuals tend to underweight idiosyncratic information in decision making (Lipe and Salterio, 2000). When common economic factors largely explain the heterogeneity of firms in the industry, these firms' earnings have high comparability.

We conjecture that earnings comparability can affect future stock price crash risk in two different ways. On the one hand, earnings comparability is widely accepted as an important earnings attribute that enhances the utility of financial statements. Due to the different accounting methods, estimates, and assumptions employed, it is difficulty for external 
information users to interpret financial statement information and evaluate alternative investment opportunities across firms (Bradshaw, Miller, and Serafeim, 2009). Earnings comparability provides benefits to information users by lowering the costs of acquiring and processing accounting information, resulting in a more transparent information environment. The resulting information transparency is likely to prevent managers from stockpiling bad news, thus reducing the likelihood that a large amount of bad news is released to the market all at once. As a result, we would expect a negative association between comparability and crash risk.

On the other hand, as firms with low comparability are likely to have more severe information asymmetry, managers generally have superior knowledge about the firm's idiosyncratic information and thus enjoy information advantage over external information users. Moreover, for firms with low earnings comparability, industry-specific information obtained from evaluating their industry peers becomes less relevant to the assessment of these firms' future performance. Information users would have to acquire more costly firm-specific information. Under this circumstance, information users' concerns about the information asymmetry and their demands for firm-specific information for firms with low comparability motivate managers to signal the market by releasing firm-specific information through voluntary disclosures (Note 2). In contrast, as comparability facilitates intra-industry information transfer (Kim and $\mathrm{Li}, 2010$ ), it is easier for investors to assess the future performance of a firm with higher comparability by analyzing the industry-specific information from its industry peers. Managers thus have incentive to disclose less firm-specific information and even to withhold some bad news, as long as their earnings comparability is high. Using a sample of restatements, Campbell and Yeung (2017) document the "herding effect" of earnings comparability that more comparable earnings captures the higher likelihood that a firm's accounting choices and estimates are similar to those of its restating peers. As a result, we would expect a positive association between comparability and crash risk. Taken together, the association between earnings comparability and stock price risk appears to be an empirical issue.

Using a large sample of 33,696 firm-year observations from the U.S. public firms for the period 1990 - 2011, we provide strong evidence that comparability is positively associated with future stock price crash risk (Note 3), after controlling for Hutton, Marcus, and Tehranian's (2009) measure of financial reporting opacity and other determinants known to influence the likelihood of the stock crash. Our results show that the effect of comparability on crash risk is comparable to that of financial reporting opacity. This finding is consistent with the notion that managers do not have much incentive to voluntarily release firm-specific information, especially the bad news of the firms, as long as their firms' financial statement is comparable to the industry peers.

After documenting a positive association between earnings comparability and crash risk, we further investigate whether this association varies with the strength of the external monitoring. Since agency conflicts between managers and shareholders lead to managerial opportunistic behaviors, we expect that the positive association between comparability and crash risk is mitigated for firm with strong external monitoring. Following prior studies (e.g., Jensen and 
Meckling 1976; Bushee, 1998; Francis, Maydew, and Sparks, 1999; Yu, 2008), we use three proxies for the strength of the external monitoring: analyst coverage, institutional ownership, and audit quality. The results from subsample analyses are consistent with the agency theory explanations for the positive association between comparability and crash risk.

In support of our main findings, we conduct several additional analyses and robustness tests. First, prior studies have documented that stock price crash risk is associated with certain earnings attributes, such as conditional conservatism (Kim and Zhang, 2016) and income smoothing (Khurana, Pereira, and Zhang, 2018). Such earnings attributes are likely to be highly correlated with earnings comparability. To isolate the effect of comparability on crash risk from other notable earnings attributes, we include conditional accounting conservatism and income smoothing as additional control variables in our main model, and our findings still hold. Second, to mitigate the potential correlated omitted variable problem, we conduct a change analysis for our main tests on the comparability and crash risk association. Our evidence shows a significantly positive association between changes in comparability and changes in measures of stock price crash risk, supporting our interpretation that comparability predicts future crash risk. Third, to assess the robustness of the main findings, we apply alternative measures of earnings comparability used by De Franco, Kothari, and Verdi (2011). Moreover, given Cheng, Hopwood, and McKeown's (1992) finding that the use of ranked accounting variables explains returns more than the raw measures, we also re-estimate our main model using ranked comparability measures. Overall, the results are robust to alternative measures and ranked variables. Finally, we further partition the full sample by high versus low information asymmetry, measured by Probability of Informed Trade (PIN) base on the Venter and de Jongh (2006) extension of the EKO model (Easley, Kiefer, and O'Hara, 1997). Results show that the positive association between comparability and crash risk only exists in the subsample of firms with high information asymmetry, consistent with our main finding.

This study contributes to the literature in several ways. First, by providing in-depth analysis of the association between earnings comparability and crash risk, this paper furthers our understanding about the capital market outcomes of earnings comparability. Specifically, although evidence from Hutton, Marcus, and Tehranian's (2009) suggests that reporting opacity is associated with higher crash risk, it is not clear regarding the role of earnings comparability as a potentially desirable earnings attribute in predicting future crash risk. Our finding contrasts with the widely accepted notion that comparability reduces information opacity and in turn reduces crash risk. Instead, it suggests that managers do not have much incentive to voluntarily release firm-specific information, especially the bad news of the firms, as long as their firms' financial statement is comparable to the industry peers. One important implication of our documented positive comparability-crash risk association is that earnings comparability does not always lead to favorable capital market outcomes.

Second, this paper extends the growing literature on the firm-specific predictors of future stock price crash risk. Specifically, following the seminal research by Jin and Myers (2006) and Hutton, Marcus, and Tehranian's (2009), recent studies provide widely firm-level evidence that stock price crash risk is associated with various factors, including equity-based 
compensation (Kim, Li and Zhang, 2011a), tax avoidance behaviors (Kim, Li, and Zhang, 2011b), conditional accounting conservatism (Kim and Zhang, 2016), institutional ownership (Callen and Fang, 2013), corporate social responsibility performance (Kim, Li, and Li, 2014), and income smoothing (Khurana, Pereira, and Zhang, 2018). Our study complement this line of study by highlighting the incremental effect of earnings comparability on future crash risk over certain common earnings attributes, such as financial reporting opacity, conditional conservatism, income smoothing.

Finally, there is a published paper by $\mathrm{Kim}, \mathrm{Li}, \mathrm{Lu}$, and $\mathrm{Yu}$ (2016) also examining the association between earnings comparability and crash risk. Our paper differs in several respects. First, we follow prior studies (e.g., Chen, Hong, and Stein, 2001) and apply two ex post measures of realized crash risk based on stock return distributions: (1) the negative conditional return skewness and (2) the down-to-up volatility of the crash likelihood. In contrast, Kim, Li, Lu, and Yu (2016) use the implied volatility smirk as the proxy for ex ante crash risk. Second, given that our paper focuses on a different perspective of crash risk from Kim, Li, Lu, and Yu (2016), our findings are different. Specifically, we find a positive association between comparability and ex post stock price crash risk, while Kim, Li, Lu, and $\mathrm{Yu}$ (2016) find a negative association between comparability and ex ante crash risk. Kim, Li, $\mathrm{Lu}$, and Yu's (2016) finding shows the benefits that earnings comparability brings into the market, consistent with the prior studies. In contrast, our finding suggests that there is a dark side to earnings comparability, which does not always lead to favorable capital market outcomes. We expect that the difference in crash risk measures applied in the two papers that results in the opposite findings and implications of earnings comparability. However, to the best of our knowledge, there is no prior studies that directly contrast and discuss the differences in construct between ex post crash risk and ex ante crash risk (Note 4). Future research may attempt to further explore the underlying differences in these two types of crash risk proxies and to reconcile the findings between our paper and Kim, Li, Lu, and Yu (2016).

The remainder of the paper is organized as follows: Section 2 reviews the relevant prior literature and develops the hypotheses. Section 3 outlines the research design including the descriptions of key variables measurement and the main empirical model. Section 4 presents the sample selection criteria and descriptive statistics. We provide our main results of testing our hypotheses in Section 5. Section 6 presents the results from additional analyses and robustness tests, and we conclude in Section 7.

\section{Prior Literature and Hypothesis Development}

\subsection{Prior Literature on Earnings Comparability}

Earnings comparability is widely accepted as an important earnings attributes and has significant implications to a firm's information environment. Due to the different accounting methods, estimates, and assumptions employed, it is difficulty for external information users to interpret financial statement information and evaluate alternative investment opportunities across firms (Bradshaw, Miller, and Serafeim, 2009). Therefore, earnings comparability provides benefits to information users through lowered costs of processing accounting outputs. Prior studies provide evidence generally consistent with this notion in various 
settings.

In the setting within the U.S., De Franco, Kothari, and Verdi (2011) find that comparability is positively associated with analyst following and forecast accuracy, and negatively associated with analysts' forecast dispersion, suggesting that comparability reduces information acquisition cost and increases the overall quantity and quality of information available to the financial analysts. More recently, other studies document that U.S. firms with more comparable financial statement have higher degree of real earnings management and lower degree of accrual based earnings management (Sohn, 2016), higher price informativeness (Choi, Choi, Myers, and Ziebart, 2017), lower cost of capital (Imhof, Seavey, and Smith, 2017), lower cash holdings (Habib, Hassan, and Al-Hadi, 2017), more profitable acquisition decisions (Chen, Collins, Kravet, and Mergenthaler, 2018), improved internal capital market efficiency and reduced diversification discounts (Cheng and $\mathrm{Wu}, 2018$ ), and lower idiosyncratic return volatility (Habib, Hassan, and Al-Hadi, 2018).

By extending the focus from the capital market to the debt market, Kim, Kraft, and Ryan (2013) document that earnings comparability reduces debt market participants' perceived credit risk. Similarly, Fang, Li, Xin, and Zhang (2016) show that comparability is associated with lower contracting cost of private loans. Furthermore, the benefits from earnings comparability have other important implications.

In the international setting, extant studies have widely examined how IFRS adoption affects earnings comparability across countries and the resulting capital market outcomes. Generally, evidence is consistent with IFRS adoption leading to capital market benefits through enhanced comparability. Specifically, the benefits of enhanced comparability driven by IFRS adoption include: increases in foreign mutual fund ownership (DeFond, Hu, Hung, and Li, 2011), improving the public information set and reducing the private information set (Brochet, Jagolinzer, and Riedl, 2011), increasing the use of accounting-based relative performance evaluation (RPE) relative to foreign peers (Ozkan, Singer, and You, 2012), enhancing accounting quality, such as earnings smoothing, accruals quality, and timeliness of earnings (Barth, Landsman, Lang, and Williams, 2012), improving liquidity, improving the forecast accuracy and other measures of the quality of information environment (Horton, Serafeim, and Serafeim, 2013), facilitating transnational information transfer (Wang, 2014), increases in firm performance, liquidity, forecast accuracy, and forecast agreement (Neel, 2017).

Most of the prior studies document various benefits of earnings comparability with two noticeable exceptions. Campbell and Yeung (2017) document the "herding effect" of earnings comparability that more comparable earnings captures the higher likelihood that a firm's accounting choices and estimates are similar to those of its restating peers. Similarly, using the South Korea setting, Lee, Kang, Lee, and Park (2016) find evidence that to prevent government from detection their illegal related party transactions, firms that conduct related party transactions are more likely to make accounting information less comparable to their industry peers. Both paper shed light on the dark side of earnings comparability. 


\subsection{Earnings Comparability and Stock Price Crash Risk}

Jin and Myers (2006) develop the theoretical framework how firm opacity links to stock price crash risk. Specifically, increase in opacity provides managers with ability and incentive to withhold firm-specific bad news from public disclosure for an extended period, resulting in severe overvaluation of the firm's share price. However, once the accumulated bad news reaches a certain tipping point, it is too costly to continue withholding bad news. When all of the accumulated bad news is suddenly disclosed at once, the stock bubble bursts, leading to stock price crashes. In support of their theory, Jin and Myers (2006) provide country-level evidence that opacity is associated with stock price crash frequencies.

Based on Jin and Myers' (2006) framework, recent studies provide firm-level evidence in the U.S. setting that stock price crash risk is associated with various factors, including financial reporting opacity captured by the magnitude of a firm's discretionary accruals (Hutton, Marcus, and Tehranian, 2009), equity-based compensation (Kim, Li and Zhang, 2011a), tax avoidance behaviors (Kim, Li, and Zhang, 2011b), institutional ownership by transient institutions (Callen and Fang, 2013), religion (Callen and Fang, 2015), short interest (Callen and Fang, 2015), proximity to the SEC (Kubick and Lockhart, 2016), conditional accounting conservatism (Kim and Zhang, 2016), takeover protection (Bhargava, Faircloth, and Zeng, 2017), stock liquidity (Chang, Chen, and Zolotoy, 2017), labor unionization (Chen, Tong, Wang, and Zhang, 2017), proportion of short-term debt (Dang, Lee, Liu, and Zeng, 2018). In the international setting, prior studies also shows evidence that crash risk is affected by IFRS adoption (DeFond, Hung, $\mathrm{Li}$, and Li, 2014), divergence of cash flow and voting Rights (Hong, Kim, and Welker, 2017), employee welfare (Ben-Nasr and Ghouma, 2018), and individualistic national culture (Dang, Faff, Luong, and Nguyen, 2018).

Our study extends this line of research by investigating how earnings comparability is associated with stock price crash risk. Specifically, we conjecture that earnings comparability can affect future stock price crash risk in two different ways. On the one hand, prior studies generally consider earnings comparability as an earnings attribute of higher quality. Since comparability lowers the information acquisition and processing costs, it increases the overall quantity and quality of the information available to the information users, resulting in a more transparent information environment. The information transparency is likely to prevent managers from stockpiling bad news and thus to reduce the likelihood that a large amount of bad news are released to the market all at once. Therefore, we would expect a negative association between comparability and crash risk.

On the other hand, as firms with low comparability are likely to have more severe information asymmetry, managers generally have superior knowledge about the firm's idiosyncratic information (e.g., firm's unique business strategy and investment opportunity) and thus enjoy information advantage over outside investors. Moreover, for firms with low earnings comparability, industry-specific information obtained from evaluating their industry peers becomes less relevant to the assessment of these firms' future performance. Hence, information users would have to acquire the more costly firm-specific information. Under this circumstance, information users' concerns about the information asymmetry and their 
needs for firm-specific information motivate managers to signal the market by releasing firm-specific information through voluntary disclosures, when firms' financial statements are less comparable with the industry peers. Consistent with this view, Gong, Li, and Zhou (2013) provide evidence that managers' propensity to provide voluntary disclosures in the form of management earnings forecast is higher when the firm's earnings have low covariance with those of its industry peers (i.e., firm with high earnings non-synchronicity). In contrast, for firms with high earnings comparability, their future performance can be easily infer from information of their industry peers. Information users have high demand of such industry-specific information, while firm-specific information becomes less important. Managers thus have incentive to disclose less firm-specific information and even to withhold some bad news, as long as their earnings comparability is high. As a result, we would expect a positive association between comparability and crash risk.

Taken together, the association between earnings comparability and stock price risk appears to be an empirical issue. Therefore, our first hypothesis is stated in the null form as follows:

\section{H1: Earnings comparability is not associated with future stock price crash risk.}

We further investigate whether the association between comparability and crash risk varies with external monitoring. Since agency conflicts between managers and shareholders lead to managerial opportunistic behaviors, we expect that the positive association between comparability and crash risk is mitigated for firm with strong external monitoring. Following prior studies, we consider three external monitoring mechanisms. First, prior studies on agency theory (e.g., Jensen and Mecling 1976) suggest that financial analysts play an important role on corporate governance. In the context of earnings management, $\mathrm{Yu}$ (2008) provides direct evidence that financial analysts can effectively curb earnings management behavior. Second, institutional investors also play a monitoring role on managers' self-serving behavior. For example, Bushee (1998) documents smaller likelihood that managers cut research and development $(\mathrm{R} \& \mathrm{D})$ expenditures to meet short-term earnings goals when institutional ownership is higher. Finally, using different proxies for audit quality, prior studies have provided evidence that higher audit quality is effective in constraining accrual-based earnings management (e.g., DeFond and Jiambalvo 1991; Becker, DeFond, Jiambalvo, and Subramanyam, 1998; Francis, Maydew, and Sparks, 1999). Therefore, our three proxies for external monitoring mechanisms are analyst coverage, institutional ownership, and audit quality. Our second hypothesis is stated in the alternative form as follows:

H2: The association between earnings comparability and future stock price crash risk is less pronounced when the firm is under strong external monitoring.

\section{Research Design}

\subsection{Measurement of Stock Price Crash Risk}

Following Chen, Hong, and Stein (2001), we apply two measures of firm-specific stock price crash risk: (1) the negative conditional return skewness (NCSKEW) and (2) the down-to-up volatility of the crash likelihood (DUVOL). Both NCSKEW and DUVOL are based on 


\section{Mll Macrothink}

International Journal of Accounting and Financial Reporting

ISSN 2162-3082

2018, Vol. 8, No. 3

firm-specific weekly returns estimated by the residual return from the following expanded market model regression:

$$
r_{i, \tau}=\alpha_{i}+\beta_{1, i} r_{m, \tau-2}+\beta_{2, i} r_{m, \tau-1}+\beta_{3, i} r_{m, \tau}+\beta_{4, i} r_{m, \tau+1}+\beta_{5, i} r_{m, \tau+2}+\epsilon_{i, \tau}
$$

where $r_{i, \tau}$ is the return on stock $\mathrm{i}$ in week $\tau$ and $r_{m, \tau}$ is the return on the CRSP value-weighted market index in week $\tau$. To allow for non-synchronous trading, the expanded market model includes the lead and lag terms for the market index return (Dimson, 1979; Scholes and Williams, 1977). In estimating equation (1), each firm year is required to have at least 26 weekly stock return observations.

Our first measure of crash risk NCSKEW for a given firm in a fiscal year is calculated by taking the negative value of the third moment of firm-specific weekly returns during the same fiscal year, scaled by the standard deviation of firm-specific weekly returns raised to the third power. The higher value of $N C S K E W$ indicates higher stock price crash risk. In particular, for each firm i in year $\mathrm{t}$, we calculate $N C S K E W$ as:

$$
\operatorname{NCSKE} W_{i, t}=-\left[n(n-1)^{\frac{3}{2}} \sum W_{i, \tau}^{3}\right] /\left[(n-1)(n-2)\left(\sum W_{i, \tau}^{2}\right)^{3 / 2}\right]
$$

where $\mathrm{n}$ is the number of observations of firm-specific weekly returns during the fiscal year $\mathrm{t}$, and $W_{i, \tau}$, is a natural logarithm of one plus the residuals obtained in equation (1), i.e., ln $\left(1+\epsilon_{i, \tau}\right)$. Higher values of $N C S K E W$ indicate firms' stock having a more left-skewed distribution, and hence, more prone to crash.

Our second measure of crash risk, DUVOL is computed without relying on the third moment and thus it is less likely to be influenced by a few extreme return observations (Chen, Hong, and Stein, 2001). For each firm i over fiscal year $t$, we separate all the weeks with firm-specific weekly returns below the annual mean ("down" weeks) from those with firm-specific returns above the annual mean ("up" weeks). We then calculate the standard deviation of the firm-specific returns for the up weeks and down weeks separately. DUVOL is a natural logarithm of the standard deviation ratio of down weeks to that of up weeks as follows:

$$
\operatorname{DUVOL}_{i, t}=-\ln \left\{\left(n_{u}-1\right) \sum_{\text {Down }} W_{i, \tau}^{2} /\left(n_{d}-1\right) \sum_{u p} W_{i, \tau}^{2}\right.
$$

where $\mathrm{n}_{\mathrm{u}}\left(\mathrm{n}_{\mathrm{d}}\right)$ is the number of $U P(D O W N)$ weeks in year t. Higher values of $D U V O L$ indicate stocks being more likely to crash.

\subsection{Measurement of Financial Reporting Comparability}

We apply the empirical methodology of De Franco, Kothari, and Verdi (2011) to construct our main measure of earnings comparability. We assess whether two firms produce comparable financial statements given the same set of economic events by estimating how stock returns map into earnings, where stock returns is the proxy for economic events and earnings is the proxy for financial statement outcomes (Note 5). For each firm-year 


\section{Macrothink}

International Journal of Accounting and Financial Reporting

ISSN 2162-3082

observation, we first estimate the following equation using the most recent 16 quarters of data:

$$
\text { Earnings }_{i, \tau}=\alpha_{i}+\beta_{i} \text { Return }_{i, \tau}+\varepsilon_{i, \tau}
$$

where Earning $s_{i, \tau}$ is the quarterly net income before extraordinary items deflated by market value of equity at the end of the previous quarter, and Return $_{i, \tau}$ is the stock return during the quarter. The estimated intercept $\widehat{\alpha}_{l}$ and slope coefficient $\widehat{\beta}_{l}$ are the proxies for the accounting system for firm $i$ in a given fiscal year. Similarly, the accounting system for another firm $\mathrm{j}$ is proxied by $\widehat{\alpha}_{J}$ and $\widehat{\beta}_{J}$, estimated using firm $\mathrm{j}$ 's earnings-returns regression over the most recent quarters for a given fiscal year. We next use firm i's and firm j's estimated accounting systems to predict their earnings conditional on the same economic events (i.e., the same stock returns). Specifically, we calculate the predicted earnings of firm i (j) given firm i's (j's) accounting system and firm i's stock returns (Note 6):

$$
\begin{aligned}
& E(\text { Earnings })_{i, i, \tau}=\widehat{\alpha}_{\imath}+\widehat{\beta}_{l} \operatorname{Return}_{i, \tau} \\
& E\left({\text { Earnings })_{i, j, \tau}}=\widehat{\alpha}_{J}+\widehat{\beta}_{J} \operatorname{Return}_{i, \tau}\right.
\end{aligned}
$$

Following De Franco, Kothari, and Verdi (2011), we define earnings comparability between firm $\mathrm{i}$ and $\mathrm{j}\left(\right.$ CompAcct $\left._{i, j, t}\right)$ as the negative value of the average absolute difference between the predicted earnings using firm i's and firm j's accounting systems:

$$
\operatorname{CompAcct}_{i, j, t}=-\frac{1}{16} * \sum_{\tau-15}^{\tau} \mid E(\text { Earnings })_{i, i, \tau}-E\left(\text { Earnings }_{i, j, \tau} \mid\right.
$$

We add a negative sign in equation (7) to facilitate interpretation, so that greater values of CompAcct $_{i, j, t}$ indicate greater earnings comparability. We estimate CompAcct $_{i, j, t}$ for each firm $\mathrm{i}-\mathrm{j}$ combination for a total of $\mathbf{J}$ firms within the same 2-digit SIC industry code as firm $\mathrm{i}$. Based on the firm-pair-year level comparability measure, we construct the firm-year measure of earnings comparability CompAcct ${ }_{i, t}$ by first ranking all the $\mathrm{J}$ values of CompAcct $_{i, j, t}$ for each firm $i$ from the highest to lowest, and taking the average value of the four firm $j$ with the highest comparability to firm i for fiscal year t. For robustness, we also apply two alternative measures: (1) CompAcct10 ${ }_{i, t}$ is the average CompAcct $_{i, j, t}$ for the ten firms with the highest comparability to firm i for fiscal year t; and (2) CompAcctInd Cot $_{i, t}$ is the median CompAcct $_{i, j, t}$ for all firm $\mathrm{j}$ in the same industry as firm $\mathrm{i}$ for the fiscal year $\mathrm{t}$.

\subsection{Empirical Model}

To examine whether earnings comparability is associated with the firm-specific stock price crash risk (H1), we follow prior studies (e.g., Hutton, Marcus, and Tehranian, 2009; Kim, Li, and Zhang, 2011a, 2011b) and estimate the following OLS regression model: 


$$
\begin{aligned}
& \mathrm{CRASH}_{\text {RISK }_{t}}=\gamma_{0}+\gamma_{1} \text { COMP }_{t-1}+\sum_{q=2}^{m} \gamma_{q} *(q \text { th Controlvariable } \text { Co-1 }) \\
& +\sum \text { Industry }+\sum Y \text { Year }+\varepsilon_{t}
\end{aligned}
$$

where our dependent variable $C R A S H_{-} R I S K_{t}$ is proxied by either NCSKEW or DUVOL, and our independent variable $C O M P_{t-1}$ is proxied by CompAcct4 in the main analysis. The regression model includes industry and year fixed effects. Consistent with the prior studies, we impose a one-year lag between the dependent variable and independent variables to test how earnings comparability predicts future crash risk. A significant positive (negative) sign on $\gamma_{1}$ indicates that the more earnings comparability, the higher (lower) future stock price crash risk.

To account for factors that may affect the likelihood of crash, we include several control variables to separate the effect of earnings comparability on crash risk. Following Chen, Hong, and Stein (2001) and Hutton, Marcus, and Tehranian (2009), the set of control variables in the model are as follows: DTURN ${ }_{t-1}, N C S K E W_{t-1}, S I G M A_{t-1}, R E T_{t-1}, \operatorname{SIZE}_{t-1}, M B_{t-1}$, $L E V_{t-1}, R O A_{t-1}$, and $O P A C I T Y_{t-1}$. Specifically, DTURN $N_{t-1}$ is the de-trended average monthly stock turnover in year $\mathrm{t}-1$, which proxies for differences of opinion among investors and is shown to be positively related to future crash risk (Chen, Hong, and Stein, 2001). NCSKEW $W_{t-1}$ is the lagged negative skewness of firm specific returns and firms with high return skewness are likely to continue to have high return skewness in the year after. $S I G M A_{t-1}$ is the standard deviation of firm-specific returns, as firms with more volatile stocks are likely to be more crash prone. $R E T_{t-1}$ is the average weekly return for the year $\mathrm{t}-1$. We include past returns because Chen, Hong, and Stein (2001) document that past returns have predictive power of future crash risk. To control for the size effects and growth effects on future crash likelihood, we include $S I Z E_{t-1}$, calculated as the natural $\log$ of market capitalization, and $M B_{t-1}$, calculated as the market value of equity divided by the book value of equity. $L E V_{t-1}$ is the total long-term debt divided by total assets, and we include leverage ratio due to its potential negative association with future crash risk (Kim, Li, and Zhang, 2011a). $R O A_{t-1}$, is the past firm performance, measured as income before extraordinary items scaled by lagged total assets.

Finally, we follow Hutton, Marcus, and Tehranian (2009) and control for financial reporting opacity $\left(O P A C I T Y_{t-1}\right)$ based on accrual-based earnings management proxy. In particular, we measure accrual-based earnings management using the discretionary accruals, estimated from the modified Jones (1991) model:

$$
\frac{T A C C_{t}}{T A_{t-1}}=\varphi_{1} \frac{1}{T A_{t-1}}+\varphi_{2} \frac{\left(\Delta R E V_{t}-\Delta R E C_{t}\right)}{T A_{t-1}}+\varphi_{3} \frac{P P E_{t}}{T A_{t-1}}+\epsilon_{t}
$$

where TACC is the total accruals, measured as income before extraordinary items less cash flows operating less cash flows from extraordinary items, following the approach in Hribar and Collins (2002), $\triangle R E V$ is the change in sales revenue, $\triangle R E V$ is the change in accounts receivable, and PPE is the net property, plant and equipment. All the variables are scaled by 
lagged total assets. We estimate Equation (9) cross-sectionally each year within the same industry group (industry is defined by two-digit SIC) to obtain the expected (non-discretionary) accruals, and the difference between the observed value and the fitted value is the discretionary accruals predicted. Since discretionary accruals can be either income-increasing or income decreasing, we use the absolute value of discretionary accruals (ABS_DACC). Consistent with Hutton, Marcus, and Tehranian (2009), we measure OPACITY as the moving sum of $A B S \_D A C C$ over the prior three years, and it is expected to be positively associated with future crash risk.

To test our second hypothesis, we focus on three proxies for external monitoring mechanisms: (1) analyst coverage (NANAL), defined as the natural logarithm of one plus the number of analysts following a firm at a specific year; (2) institutional ownership (IO), defined as the natural logarithm of one plus the ratio of institutional owner holding to total shares outstanding for a firm at a specific year; (3) audit quality (Big4), defined as a dummy variable that takes value of one if a firm is audited by a Big 4 auditor at a specific year, and zero otherwise. We classify firms within the top (bottom) quintile of $N A N A L$, within the top (bottom) quintile of $I O$, or audited by Big4 (Non-Big4) auditors, as firms with strong (weak) external monitoring. Then, we re-examine the association between earnings comparability and stock price crash risk separately for the subsample with strong and with weak external monitoring.

\section{Sample Selection and Descriptive Statistics}

\subsection{Sample Selection}

Our initial sample firms comprise the intersection of data from COMPUSTAT and the Center for Research in Security Prices (CRSP) from 1990 to 2011. The sample period starts from 1990 because it is the first year for which we are able to estimate the financial reporting opacity measure based on three annual lags of discretionary accruals using the Statement of Cash Flow method. We then impose sample selection criteria as follows. First. To calculate the comparability measure, we follow De Franco, Kothari, and Verdi (2011) and include only those industries (industry is defined as the two-digit SIC code) with at least 10 observations in the year. Second, following Hutton, Marcus, and Tehranian (2009), we exclude firms with average annual stock prices less than $\$ 2.50$ to minimize the effects of small firms, and we require firms should have at least 26 weekly returns for each year. Third, we exclude firms from the financial (SIC 6000-6999) and utility (SIC 4000-4999) industries. Finally, we exclude firm-year observations with missing data to compute the regression variables. To mitigate the effects of outliners, we winsorize all the continuous variables that lie in the top or bottom one percent of the distributions. Our final sample consists of 33,696 observations.

\subsection{Descriptive Statistics}

Table 1 presents the descriptive statistics for the key variables used in our main analyses. The statistics for our two measures of stock price crash risk is largely comparable to that reported in the prior studies. The mean (median) values of $N C S K E W_{t}$ and $D U V O L_{t}$ are $-0.019(-0.048)$ and -0.071 (-0.082), respectively. Also, similar to De Franco, Kothari, and Verdi (2011), the 
mean (median) values of CompAcct4 and CompAcctInd are -0.544 (-0.260) and -2.319 (-1.710), respectively. Regarding our main partition variables that proxy for external monitoring, the mean (median) values of NANAL and IO are 1.492 (1.609) and 0.442 (0.443), respectively, comparable with the statistics reported in Kim, Li, and Zhang (2011a). The mean value of the BIG4 dummy is

Table 1. Descriptive statistics

\begin{tabular}{|c|c|c|c|c|c|c|c|}
\hline VARIABLES & Mean & Std Dev & $5 \%$ & $25 \%$ & $50 \%$ & $75 \%$ & $95 \%$ \\
\hline NCSKEW $_{t}$ & -0.019 & 0.824 & -1.232 & -0.454 & -0.049 & 1.308 & 6.678 \\
\hline DUVOL $_{t}$ & -0.071 & 0.367 & -0.651 & -0.309 & -0.082 & 0.549 & 2.026 \\
\hline CompAcct $4_{t-1}$ & -0.543 & 0.752 & -2.280 & -0.590 & -0.260 & -0.050 & -0.010 \\
\hline $\operatorname{CompAcct10}_{\mathrm{t}-1}$ & -0.795 & 1.027 & -3.200 & -0.910 & -0.400 & -0.090 & -0.030 \\
\hline CompAcctInd $_{t-1}$ & -2.320 & 1.813 & -6.460 & -2.710 & -1.710 & -0.730 & -0.290 \\
\hline OPACITY $_{\mathrm{t}-1}$ & 0.289 & 0.245 & 0.058 & 0.130 & 0.223 & 0.739 & 3.037 \\
\hline DTURN $_{t-1}$ & 0.030 & 0.810 & -1.174 & -0.200 & 0.006 & 1.316 & 3.419 \\
\hline NCSKEW $_{t-1}$ & -0.018 & 0.790 & -1.184 & -0.447 & -0.050 & 1.259 & 6.556 \\
\hline SIGMA $_{t-1}$ & 0.059 & 0.030 & 0.023 & 0.037 & 0.053 & 0.116 & 0.552 \\
\hline $\mathbf{R E T}_{\mathrm{t}-1}$ & -0.217 & 0.286 & -0.663 & -0.272 & -0.136 & -0.027 & -0.001 \\
\hline SIZE $_{t-1}$ & 5.797 & 2.080 & 2.641 & 4.252 & 5.669 & 9.480 & 13.081 \\
\hline $\mathbf{M B}_{\mathrm{t}-1}$ & 2.974 & 3.351 & 0.614 & 1.257 & 2.041 & 8.240 & 29.219 \\
\hline $\mathbf{L E V}_{\mathrm{t}-1}$ & 0.165 & 0.163 & 0 & 0.008 & 0.132 & 0.481 & 0.929 \\
\hline $\mathbf{R O A}_{t-1}$ & 0.015 & 0.083 & -0.128 & 0.008 & 0.031 & 0.089 & 0.549 \\
\hline NANAL $_{t-1}$ & 1.491 & 1.134 & 0 & 0 & 1.609 & 3.258 & 4.111 \\
\hline $\mathbf{I O}_{\mathrm{t}-1}$ & 0.442 & 0.308 & 0 & 0.158 & 0.443 & 0.927 & 2.436 \\
\hline BIG4 $_{t-1}$ & 0.362 & 0.481 & 0 & 0 & 0 & 1 & 1 \\
\hline
\end{tabular}


This table presents descriptive statistics for measures of stock price crash risk, earnings comparability, earnings opacity, control variables, and main partition variables. The sample includes 33,696 firm-year observations over the period 1990 to 2001. See Appendix A for variable definitions.

Table 2. Pearson and spearman correlations

\begin{tabular}{|c|c|c|c|c|c|c|c|c|c|c|}
\hline No & VARIABLES & (1) & (2) & (3) & (4) & (5) & (6) & (7) & (8) & (9) \\
\hline (1) & NCSKEW $_{\mathrm{t}}$ & - & 0.950 & 0.074 & 0.073 & 0.053 & 0.023 & 0.144 & 0.144 & 0.046 \\
\hline (2) & DUVOL $_{t}$ & 0.978 & - & 0.087 & 0.086 & 0.075 & 0.017 & 0.160 & 0.162 & 0.056 \\
\hline (3) & $\operatorname{CompAcct}_{\mathrm{t}-1}$ & 0.056 & 0.066 & - & 0.979 & 0.598 & -0.084 & 0.313 & 0.263 & 0.112 \\
\hline (4) & CompAcct $10_{t-1}$ & 0.055 & 0.064 & 0.977 & - & 0.592 & -0.067 & 0.306 & 0.259 & 0.105 \\
\hline (5) & CompAcctInd $_{t-1}$ & 0.042 & 0.066 & 0.781 & 0.788 & - & -0.336 & 0.274 & 0.250 & 0.081 \\
\hline (6) & OPACITY $_{\mathrm{t}-1}$ & 0.029 & $0.011^{*}$ & -0.103 & -0.098 & -0.258 & - & -0.135 & -0.080 & -0.105 \\
\hline (7) & NANAL $_{t-1}$ & 0.137 & 0.160 & 0.242 & 0.238 & 0.239 & -0.105 & - & 0.719 & 0.370 \\
\hline (8) & $\mathrm{IO}_{\mathrm{t}-1}$ & 0.142 & 0.167 & 0.192 & 0.189 & 0.213 & -0.079 & 0.711 & - & 0.368 \\
\hline (9) & BIG4 $_{t-1}$ & 0.049 & 0.058 & 0.066 & 0.060 & 0.057 & -0.103 & 0.382 & 0.384 & - \\
\hline
\end{tabular}

This table presents the pairwise Pearson (below the diagonal) and Spearman (above the diagonal) correlations for measures of stock price crash risk, earnings comparability, earnings opacity, and main partition variables. The sample includes 33,696 firm-year observations over the period 1990 to 2001 . The unmarked correlations are statistically significant at $1 \%$ level. or lower, * indicates statistically significant at 1\%-5\% level. See Appendix A for variable definitions. 0.363 , indicating that about one third of the firms in our sample are audited by Big 4 auditors. All control variables have distributions consistent with those reported in the prior studies and exhibit significant cross-sectional variations.

Table 2 presents the Pearson (below the diagonal) and Spearman (above the diagonal) correlations among future stock price crash risk measures, earnings comparability measures, financial reporting opacity, and the three external monitoring proxies. The results of the univariate analyses are summarized as follows. First, the two cash risk measures $\left(N C S K E W_{t}\right.$ and $\left.D U V O L_{t}\right)$ are highly correlated, suggesting that the two alternative measures capture similar information. So as the three comparability measures (CompAcct $4_{t-1}$, CompAcct10 $0_{t-1}$, CompAcctInd $\left._{t-1}\right)$. Second, the correlations between crash risk measures and comparability measures are all significantly positive, providing preliminary univariate evidence of the positive association between comparability and future crash risk. Moreover, the measures of financial reporting opacity are positively correlated with both measures of crash risk, consistent with the findings in Hutton, Marcus, and Tehranian (2009). Finally, our comparability measures are negatively associated with financial reporting opacity and positively associated with external monitoring variables, consistent with the generally accepted notion that comparability represents an earnings attribute with higher earnings quality.

\section{Empirical Results}

\subsection{The Association Between Comparability and Crash Risk}

Table 3 presents the OLS regression results of estimating Equation (8) to test our first 


\section{1l Macrothink}

International Journal of Accounting and Financial Reporting

ISSN 2162-3082

2018, Vol. 8, No. 3

hypothesis on the association between earnings comparability and crash risk. We use the alternative measure of crash risk NCSKEW and DUVOL, respectively, as our dependent variable. When estimating the coefficient standard errors, we correct for heteroskedasticity following White (1980) and use a firm-level clustering procedure that accounts for serial dependence across years for a given firm (Petersen, 2009).

When using NCSKEW to measure crash risk, we show results in Column (1) of Table 3 that the coefficient on our variable of interests CompAcct4 is positive and significant at 1 percent level $(0.038, \mathrm{t}=6.05)$. The results suggest that managers have incentive to disclose less firm-specific information and even to withhold some bad news, as long as their earnings comparability is high, and their firms' future performance can be easily infer from information of industry peers. In other words, the finding is consistent with the information garbling view that earnings comparability contributes to bad news concealment, leading to higher crash risk as captured by the extreme negative return skewness.

Column (1) of Table 3 also show that the coefficients on the control variables are largely consistent with those reported in the prior studies. First, the coefficient on the lagged term of OPACITY is significantly positive $(0.081, \mathrm{t}=3.91)$, consistent with Hutton, Marcus, and Tehranian's (2009) finding that higher opacity results in higher stock price crash risk. In addition, we find the significantly positive coefficients on the lagged terms of DTURN, NCSKEW, SIGMA, RET, SIZE, MB (0.03, $\mathrm{t}=5.3 ; 0.033, \mathrm{t}=5.85 ; 2.314, \mathrm{t}=6.13 ; 0.206, \mathrm{t}=6.07$; $0.049, \mathrm{t}=16.97 ; 0.013, \mathrm{t}=9.44$, respectively) and negative coefficient on the lagged term of $\operatorname{LEV}(-0.168, \mathrm{t}=-5.46)$, largely in line with the results reported in Chen, Hong, and Stein (2001), Hutton, Marcus, and Tehranian (2009), and Kim, Li, and Zhang (2011a, 2011b).

Table 3. Earnings comparability and stock price crash risk

\begin{tabular}{|c|c|c|c|}
\hline VARIABLES & Pred. Sign & NCSKEW $_{t}$ & DUVOL $_{t}$ \\
\hline \multirow[t]{2}{*}{$\operatorname{CompAcct} 4_{t-1}$} & $?$ & $0.038 * * *$ & $0.018 * * *$ \\
\hline & & $(6.05)$ & $(6.53)$ \\
\hline \multirow[t]{2}{*}{$\operatorname{OPACITY}_{\mathrm{t}-1}$} & + & $0.081 * * *$ & $0.030 * * *$ \\
\hline & & $(3.91)$ & $(3.31)$ \\
\hline \multirow[t]{2}{*}{ DTURN $_{t-1}$} & + & $0.030 * * *$ & $0.016^{* * *}$ \\
\hline & & $(5.30)$ & $(6.14)$ \\
\hline NCSKEW $_{t-1}$ & + & $0.033 * * *$ & $0.014 * * *$ \\
\hline
\end{tabular}


SIGMA $_{\text {t-1 }}$

$\boldsymbol{R E T}_{\text {t-1 }}$

SIZE $_{t-1}$

$\mathbf{M B}_{\text {t-1 }}$

$\mathbf{L E V}_{\mathrm{t}-1}$

ROA $_{t-1}$

\section{Constant}

$?$

$-0.168 * * *$

$0.436^{* * *}$

$-0.782 * * *$

YES

YES

33,696

0.0394
$0.359^{* *}$

$0.072 * * *$

$0.024 * * *$

$0.006 * * *$

$-0.083 * * *$

$0.276 * * *$

(10.20)

$-0.381 * * *$

YES

YES

33,696

0.0545

This table presents OLS regressions to examine the association between earnings comparability and stock price crash risk. When estimating the coefficient standard errors, we correct for heteroskedasticity following White (1980) and use a firm-level clustering procedure that accounts for serial dependence across years for a given firm (Petersen, 2009). Two-tailed t-statistics are presented in the parentheses. *,**, and *** denote t-statistics are significant at 10,5, and $1 \%$ level. See Appendix A for variable definitions. 


\section{MlMacrothink}

International Journal of Accounting and Financial Reporting ISSN 2162-3082 2018, Vol. 8, No. 3

Column (2) of Table 3 reports the results estimated using DUVOL as the dependent variable. The results are very comparable to those reported in Column (1), with the significantly positive coefficient on CompAcct4 $(0.018, \mathrm{t}=6.53)$, and significant coefficients on other control variables with predicted sign. Overall, the results in Table 3 provide strong and consistent evidence that earnings comparability is positively associated with future stock price crash risk.

\subsection{Subsample Analyses: The Role of External Monitoring}

In this section, we test our second hypothesis on whether the documented positive association between earnings comparability and crash risk varies with external monitoring. Under $\mathrm{H} 2$, we expect the positive association is diminished for firms with strong external monitoring, and we test this hypothesis using subsample analyses.

Panel A of Table 4 reports the results of estimating Equation (8) for subsamples partitioned based on analyst coverage. We find a significantly positive coefficient on our variable of interests CompAcct4 when firms have lower analyst coverage (i.e., the value of NANAL lies in the bottom quintile), consistent with our main finding. The results is robust for both measures of crash risk for $(0.029, \mathrm{t}=2.77$ for $N C S K E W ; 0.014, \mathrm{t}=2.97$ for $D U V O L)$. In contrast, the coefficient on CompAcct4 becomes insignificant $(-0.015, \mathrm{t}=-0.65$ for NCSKEW and $-0.004, \mathrm{t}=-0.41$ for $D U V O L)$. In Panel B and Panel C, we partition the sample based on institutional ownership and audit quality. Similarly, we find that earnings comparability is significantly and positively associated with future crash risk (both NCSKEW and DUVOL) for firms with low institutional ownership or firms audited by non-Big 4 auditors, while the positive association become insignificant for subsample of firms with high institutional ownership or firms audited by Big 4 auditors. Overall, the results presented in Table 4 suggest that earnings comparability is a strong predictor for future crash risk only for firms with less effective external monitoring, but it does not have much impact on crash risk for firms with strong external monitoring.

\section{Additional Analyses and Robustness Tests}

\subsection{Additional Control of Other Earnings Attributes}

Prior studies have documented that stock price crash risk is associated with certain earnings attributes, such as conditional conservatism (Kim and Zhang, 2016) and income smoothing (Khurana, Pereira, and Zhang, 2018). Such earnings attributes are likely to be highly correlated with earnings comparability (e.g., De Franco, Kothari, and Verdi. 2011; Peterson, Schmardebeck, and Wilks, 2012). Therefore, our results could be driven by alternative explanations that our earnings comparability measure merely captures the effects of other earnings attributes. To isolate the effect of comparability on crash risk from these notable earnings attributes, we include conditional accounting conservatism and income smoothing as additional control variables in our main model to see whether our findings still hold.

We measure the degree of conditional accounting conservatism using the firm-year conditional conservatism measure, CSCORE, developed by Khan and Watts (2009). To obtain the CSCORE measure, we begin with the Basu (1997) model, which is designed to 
capture the asymmetric timeliness of earnings in recognizing bad news versus good news. Specifically, the Basu model can be written to allow coefficients to vary across firms and over time as follows:

Table 4. Subsample analyses - the role of external monitoring

Panel A. Partition by analyst following

\begin{tabular}{|c|c|c|c|c|}
\hline & NCSKEW $_{t}$ & & DUVOL $_{t}$ & \\
\hline VARIABLES & Low NANAL & High NANAL & Low NANAL & High NANAL \\
\hline \multirow[t]{2}{*}{$\operatorname{CompAcct} 4_{t-1}$} & $0.029 * * *$ & -0.015 & $0.014 * * *$ & -0.004 \\
\hline & $(2.77)$ & $(-0.65)$ & (2.97) & $(-0.41)$ \\
\hline \multirow[t]{2}{*}{$\operatorname{OPACITY}_{\mathrm{t}-1}$} & $0.086 * *$ & 0.085 & 0.029 & 0.033 \\
\hline & $(2.00)$ & $(1.58)$ & $(1.52)$ & $(1.41)$ \\
\hline \multirow[t]{2}{*}{ DTURN $_{\text {t-1 }}$} & $0.031 * *$ & 0.016 & $0.017 * * *$ & 0.008 \\
\hline & $(2.46)$ & $(1.28)$ & $(3.01)$ & $(1.57)$ \\
\hline \multirow[t]{2}{*}{ NCSKEW $_{t-1}$} & $0.037 * * *$ & 0.003 & $0.016^{* * *}$ & 0.000 \\
\hline & $(3.10)$ & $(0.25)$ & $(2.98)$ & $(0.03)$ \\
\hline \multirow[t]{2}{*}{ SIGMA $_{t-1}$} & $2.162 * * *$ & $6.638 * * *$ & 0.075 & $2.117 * * *$ \\
\hline & $(3.01)$ & $(3.78)$ & $(0.23)$ & $(2.72)$ \\
\hline \multirow[t]{2}{*}{ RET $_{t-1}$} & $0.168 * * *$ & $1.003 * * *$ & 0.037 & $0.404 * * *$ \\
\hline & $(2.70)$ & $(4.15)$ & $(1.33)$ & $(3.78)$ \\
\hline \multirow[t]{2}{*}{$\operatorname{SIZE}_{t-1}$} & $0.059 * * *$ & $-0.015^{*}$ & $0.027 * * *$ & -0.005 \\
\hline & $(9.73)$ & $(-1.75)$ & $(10.00)$ & $(-1.29)$ \\
\hline \multirow[t]{2}{*}{$\mathbf{M B}_{\mathrm{t}-1}$} & $0.013 * * *$ & $0.011^{* * *}$ & $0.007 * * *$ & $0.006 * * *$ \\
\hline & $(4.74)$ & $(3.57)$ & $(5.23)$ & $(3.92)$ \\
\hline
\end{tabular}




\begin{tabular}{|c|c|c|c|c|}
\hline $\begin{array}{l}\text { Wacro } \\
\text { mstitu }\end{array}$ & 15 & International Journal o & Accounting and & $\begin{array}{l}\text { Financial Reporting } \\
\text { ISSN 2162-3082 } \\
\text { 2018, Vol. 8, No. } 3\end{array}$ \\
\hline \multirow[t]{2}{*}{$\mathbf{L E V}_{t-1}$} & $-0.130 * *$ & $-0.222 * * *$ & $-0.064 * *$ & $-0.111 * * *$ \\
\hline & $(-1.96)$ & $(-2.92)$ & $(-2.18)$ & $(-3.28)$ \\
\hline \multirow[t]{2}{*}{$\mathbf{R O A}_{t-1}$} & $0.400 * * *$ & $0.305^{*}$ & $0.253 * * *$ & $0.256^{* * *}$ \\
\hline & $(3.70)$ & (1.68) & $(5.30)$ & $(3.19)$ \\
\hline \multirow[t]{2}{*}{ Constant } & -0.461 & -0.341 & -0.234 & -0.155 \\
\hline & $(-0.56)$ & $(-0.59)$ & $(-0.65)$ & $(-0.60)$ \\
\hline Industry Fixed Effect & YES & YES & YES & YES \\
\hline Year Fixed Effect & YES & YES & YES & YES \\
\hline Observations & 7,614 & 6,783 & 7,614 & 6,783 \\
\hline Adj. R-squared & 0.0621 & 0.0415 & 0.0621 & 0.0415 \\
\hline
\end{tabular}

Panel B. Partition by institutional ownership

\begin{tabular}{|c|c|c|c|c|}
\hline & NCSKEY & & DUVOL $_{t}$ & \\
\hline VARIABLES & Low IO & High IO & Low IO & High IO \\
\hline \multirow[t]{2}{*}{$\operatorname{CompAcct}_{\mathrm{t}-1}$} & $\mathbf{0 . 0 3 0} * * *$ & -0.001 & $0.014 * * *$ & 0.003 \\
\hline & $(2.63)$ & $(-0.04)$ & $(2.82)$ & $(0.36)$ \\
\hline \multirow[t]{2}{*}{ OPACITY $_{t-1}$} & $0.093 * *$ & $0.177 * * *$ & $0.074 * * *$ & 0.030 \\
\hline & $(2.19)$ & $(2.97)$ & $(2.81)$ & $(1.59)$ \\
\hline \multirow[t]{2}{*}{ DTURN $_{t-1}$} & 0.016 & 0.016 & 0.009 & 0.006 \\
\hline & $(1.29)$ & $(1.22)$ & $(1.56)$ & (1.12) \\
\hline \multirow[t]{2}{*}{ NCSKEW $_{t-1}$} & $0.058 * * *$ & -0.021 & $0.025^{* * *}$ & -0.008 \\
\hline & $(4.48)$ & $(-1.54)$ & $(4.30)$ & $(-1.37)$ \\
\hline
\end{tabular}


SIGMA $_{t-1}$

RET $_{\text {t-1 }}$

$\mathbf{M B}_{\mathrm{t}-1}$

ROA $_{\text {t-1 }}$

$\mathbf{L E V}_{\mathrm{t}-1}$

Constant

$-0.975$

$(-1.22)$

Industry Fixed Effect

Year Fixed Effect

Observations

Adj. R-squared

0.395

$(0.63)$

0.030

(0.72)

(8.31)

(5.18)

$-0.099$

$(-1.41)$

(4.10)

YES
0.0708

6,114

0.0708
$0.053 * * *$

$0.015^{* * *}$

$0.456^{* * *} *$

(3.60)

(5.73)

(5.39)

$-0.122 *$

$(-1.67)$

$(-1.48)$

$0.285^{* * *}$

$0.498 * * *$

(4.90)

$-1.626 * * *$

$(-2.64)$

$(-1.95)$

$(-3.02)$

YES

YES

6,762

0.0376

YES

YES

YES

YES

6,114

6,762

$-0.820 * * *$ 


\section{Macrothink International Journal of Accounting and Financial Reporting

Panel C. Partition by auditor quality

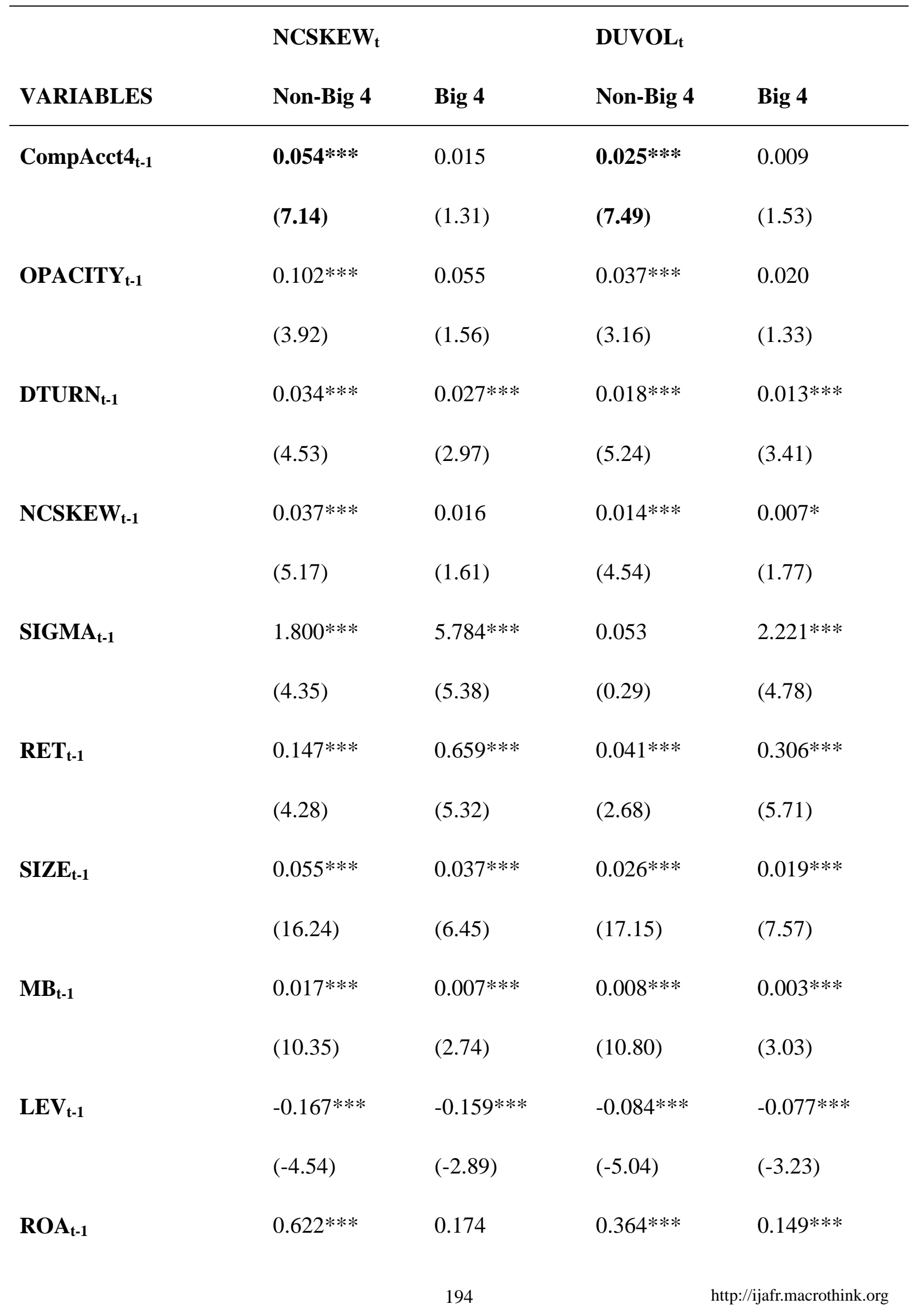


$(8.48)$

$-0.737 * *$

$-0.967$

YES

YES

21,466

12,230

0.0307

0.0641
(11.08)

$-0.453$

YES

YES

YES

YES

12,230

21,466

12,230

Adj. R-squared

0.0641

0.0307

This table presents OLS regressions to examine the association between earnings comparability and stock price crash risk for firms audited by Big 4 auditors and those audited by Non-Big 4 auditors. When estimating the coefficient standard errors, we correct for heteroskedasticity following White (1980) and use a firm-level clustering procedure that accounts for serial dependence across years for a given firm (Petersen, 2009). Two-tailed $\mathrm{t}$-statistics are presented in the parentheses. $*, * *$, and $* * *$ denote $\mathrm{t}$-statistics are significant at 10, 5, and $1 \%$ level. See Appendix A for variable definitions.

$$
E A R N_{j t}=\beta_{1 j t}+\beta_{2 j t} D_{j t}+\beta_{3 j t} R E T_{j t}+\beta_{4 j t} D_{j t} * R E T_{j t}+\varepsilon_{i t}
$$

where $E A R N$ is earnings before extraordinary items scaled by lagged market value of equity; $R E T$ is contemporaneous annual stock returns calculated using CRSP monthly return data; D is a dummy variable that equals one if $R E T<0$, and zero otherwise. The firm-year coefficient $\beta_{3 j t}$ (i.e., timeliness of good news) and $\beta_{4 j t}$ (conservatism) are then expressed by linear functions of firm-year-specific characteristics that are correlated with the timeliness of good news and conservatism:

$$
\begin{aligned}
& \operatorname{GSCORE}_{j t}=\beta_{3 j t}=\mu_{1 t}+\mu_{2 t} \mathrm{MV}_{j t}+\mu_{3 t} M B_{j t}+\mu_{4 t} L E V_{1 t} \\
& \operatorname{CSCORE}_{j t}=\beta_{4 j t}=\lambda_{1 t}+\lambda_{2 t} \mathrm{MV}_{j t}+\lambda_{3 t} M B_{j t}+\lambda_{4 t} L E V_{1 t}
\end{aligned}
$$

where $M V$ is the natural $\log$ of the market value; $M B$ is the market value of equity divided by the book value of equity; $L E V$ is the total debt divided by total assets. Plugging Equation (11) and (12) into Equation (9) yields the following Equation (13). We estimate Eq. (13) using five-year rolling panel regressions 4 and calculate our measure of conservatism, CSCORE, using Equation (12) with the estimated coefficients from Equation (13). Firms with a higher CSCORE are considered more conservative. 


$$
\begin{aligned}
E A R N_{j t} & =\beta_{1 j t}+\beta_{2 j t} D_{j t}+R E T_{j t} *\left(\lambda_{1 t}+\lambda_{2 t} \mathrm{MV}_{j t}+\lambda_{3 t} M B_{j t}+\lambda_{4 t} L E V_{1 t}\right) \\
& +D_{j t} * R E T_{j t} *\left(\lambda_{1 t}+\lambda_{2 t} \mathrm{MV}_{j t}+\lambda_{3 t} M B_{j t}+\lambda_{4 t} L E V_{1 t}\right) \\
& +\left(\delta_{1 t} \mathrm{MV}_{j t}+\delta_{2 t} M B_{j t}+\delta_{3 t} L E V_{1 t}+\delta_{4 t} D_{j t} * \mathrm{MV}_{j t}+\delta_{5 t} D_{j t} * M B_{j t}\right. \\
& \left.+\delta_{6 t} D_{j t} * L E V_{1 t}\right)+\varepsilon_{i t}
\end{aligned}
$$

The measure we use to proxy for income smoothing (SMOOTH) follows Francis, LaFond, Olsson, and Schipper (2004). In particular, SMOOTH is measured as the volatility of income with respect to the volatility of cash flows over the most recent five-year rolling window (Equation 14).

$$
\text { SMOOTH } H_{i t}=\frac{\operatorname{StdDev}\left(\frac{C F O_{i t}}{T A_{i t-1}}\right)}{\operatorname{StdDev}\left(\frac{N I_{i t}}{T A_{i t-1}}\right)}
$$

where $N I$ is the net income before extraordinary items; $C F O$ is the Cash flows from operations less cash flows from extraordinary items, following the approach in Hribar and Collins (2002); TA is the total assets. The more income smoothing a manager engages in, the higher the variability of cash flows with respect to the variability of income will be. Thus, a higher ratio signifies a smoother income stream.

The results reported in Table 5 show that the positive association between earnings comparability and crash risk are always significant by including either CSCORE, SMOOTH, or both of these two attributes at the same time. In addition, across different specifications, the coefficients on CSCORE are always significantly negative, consistent with those documented by Kim and Zhang (2016), and the coefficients on SMOOTH are always significantly positive, consistent with those 
Table 5. Additional controls for other earnings attributes

\begin{tabular}{|c|c|c|c|c|c|c|}
\hline & & NCSKEW $_{\mathrm{t}}$ & & & DUVOL $_{t}$ & \\
\hline CompAcct $_{t-1}$ & $\begin{array}{c}0.029 * * * \\
(3.87)\end{array}$ & $\begin{array}{c}0.036 * * \\
(4.73)\end{array}$ & $\begin{array}{c}0.028 * * \\
(3.67)\end{array}$ & $\begin{array}{c}0.015 * * * \\
(4.44)\end{array}$ & $\begin{array}{c}0.017 * * * \pi \\
(5.21)\end{array}$ & $\begin{array}{c}0.014 * * \\
(4.18)\end{array}$ \\
\hline $\operatorname{CSCORE}_{\mathrm{t}-1}$ & $\begin{array}{c}-0.312 * * \\
(-7.48)\end{array}$ & & $\begin{array}{c}-0.312 * * \\
(-7.46)\end{array}$ & $\begin{array}{c}-0.135 * * * \\
(-7.31)\end{array}$ & & $\begin{array}{c}-0.135 * * * \\
(-7.28)\end{array}$ \\
\hline SMOOTH $_{\mathrm{t}-\mathrm{l}}$ & & $\begin{array}{c}0.005^{*} \\
(1.79)\end{array}$ & $\begin{array}{c}0.005^{* *} \\
(2.12)\end{array}$ & & $\begin{array}{c}0.002 * * \\
(2.17)\end{array}$ & $\begin{array}{c}0.003 * * \\
(2.51)\end{array}$ \\
\hline OPACITY $_{t-1}$ & $\begin{array}{c}0.075^{\text {**** }} \text { * } \\
(3.44)\end{array}$ & $\begin{array}{c}0.079 * * * * \\
(3.58)\end{array}$ & $\begin{array}{c}0.076^{\text {*2*** }} \\
(3.44)\end{array}$ & $\begin{array}{c}0.028^{* * * * *} * \\
(2.88)\end{array}$ & $\begin{array}{c}0.029 \text { **** } \\
(2.99)\end{array}$ & $\begin{array}{c}0.028^{* * * *} \\
(2.86)\end{array}$ \\
\hline DTURN $_{t-1}$ & $\begin{array}{c}0.031^{*} \text { ***** } \\
(5.02)\end{array}$ & $\begin{array}{c}0.032^{* * * *} \text { * } \\
(5.30)\end{array}$ & $\begin{array}{c}0.030^{* * * *} \\
(4.96)\end{array}$ & $\begin{array}{c}0.015^{* * * *} \\
(5.75)\end{array}$ & $\begin{array}{c}0.016^{\text {*k*k }} \\
(6.04)\end{array}$ & $\begin{array}{c}0.015^{\text {***** }} \\
(5.69)\end{array}$ \\
\hline NCSKEW $_{t-1}$ & $\begin{array}{c}0.030^{*} \text { *** } * \\
(4.98)\end{array}$ & $\begin{array}{c}0.030 * * * \\
(5.03)\end{array}$ & $\begin{array}{c}0.030^{* * * *} \\
(4.97)\end{array}$ & $\begin{array}{c}0.012^{* * * * *} \\
(4.73)\end{array}$ & $\begin{array}{c}0.013^{* * * * *} \\
(4.80)\end{array}$ & $\begin{array}{c}0.013^{* * * *} \\
(4.74)\end{array}$ \\
\hline SIGMA $_{t-1}$ & $\begin{array}{c}2.567^{*} * * * \\
(6.54)\end{array}$ & $\begin{array}{c}2.492^{* * * *} \\
(6.32)\end{array}$ & $\begin{array}{c}2.659^{* * * *} \\
(6.73)\end{array}$ & $\begin{array}{c}0.492^{* * * *} \\
(2.83)\end{array}$ & $\begin{array}{c}0.462^{* * * * *} \\
(2.65)\end{array}$ & $\begin{array}{c}0.537^{* * * *} \\
(3.07)\end{array}$ \\
\hline $\mathbf{R E T}_{\mathrm{t}-\mathrm{l}}$ & $\begin{array}{c}0.218^{* * * *} \\
(6.25)\end{array}$ & $\begin{array}{c}0.214^{*} * * * \\
(6.14)\end{array}$ & $\begin{array}{c}0.222^{* * * *} \cdot{ }^{*} \\
(6.36)\end{array}$ & 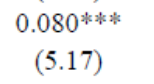 & $\begin{array}{c}0.078^{* * * *} \\
(5.08)\end{array}$ & $\begin{array}{c}0.082^{*} \text { **** } \\
\quad(5.30)\end{array}$ \\
\hline $\operatorname{SIZE}_{t-1}$ & $\begin{array}{c}0.031 \text { **** } \\
(7.93)\end{array}$ & $\begin{array}{c}0.051^{* * * *} \\
(16.36)\end{array}$ & $\begin{array}{c}0.032^{* * * *} \\
(7.94)\end{array}$ & $\begin{array}{c}0.016^{* * * *} \\
(9.16)\end{array}$ & $\begin{array}{c}0.024^{* * * *} \\
(17.79)\end{array}$ & $\begin{array}{c}0.016^{* * * *} \\
(9.17)\end{array}$ \\
\hline $\mathrm{MB}_{\mathrm{t}-1}$ & $\begin{array}{c}0.008^{*} * * * \\
(4.63)\end{array}$ & $\begin{array}{c}0.013^{*} * * * \\
(8.62)\end{array}$ & $\begin{array}{c}0.007^{* * * *} \\
(4.48)\end{array}$ & $\begin{array}{c}0.004 * * * \\
(5.11)\end{array}$ & $\begin{array}{c}0.006^{*} \text { * } * * \\
(9.07)\end{array}$ & $\begin{array}{c}0.004^{* * * * *} \\
(4.98)\end{array}$ \\
\hline $\operatorname{LEV}_{\mathrm{t}-1}$ & $\begin{array}{c}-0.081^{* * *} \\
(-2.36)\end{array}$ & $\begin{array}{c}-0.169 * * * * \\
(-5.23)\end{array}$ & $\begin{array}{c}-0.078^{* *} \\
(-2.25)\end{array}$ & $\begin{array}{c}-0.047^{* * * *} \\
(-3.12)\end{array}$ & $\begin{array}{c}-0.086^{* * * *} \\
(-5.98)\end{array}$ & 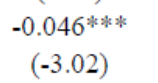 \\
\hline $\mathbf{R O A}_{t-1}$ & $\begin{array}{c}0.436^{*} * * * \\
(6.72)\end{array}$ & $\begin{array}{c}0.429 * * * * \\
(6.53)\end{array}$ & $\begin{array}{c}0.420^{* * * *} \\
(6.39)\end{array}$ & $\begin{array}{c}0.275^{*} \text { *** } \\
(9.59)\end{array}$ & $\begin{array}{c}0.272^{*} * * * \\
(9.38)\end{array}$ & $\begin{array}{c}0.268^{* * * *} \\
(9.24)\end{array}$ \\
\hline Constant & $\begin{array}{c}-0.666^{*} \\
(-1.81)\end{array}$ & $\begin{array}{c}-0.778^{* *} \cdot \\
(-2.13)\end{array}$ & $\begin{array}{c}-0.755^{* *} \\
(-2.08)\end{array}$ & $\begin{array}{c}-0.352^{* * *} \\
(-2.16)\end{array}$ & $\begin{array}{c}-0.397^{* *} * \\
(-2.46)\end{array}$ & $\begin{array}{c}-0.402 * * \\
(-2.50)\end{array}$ \\
\hline Industry Fixed Effect & YES & YES & YES & YES & YES & YES \\
\hline Year Fixed Effect & YES & YES & YES & YES & YES & YES \\
\hline Observations & 30,965 & 30,739 & 30,699 & 30,965 & 30,739 & 30,699 \\
\hline Adj. R-squared & 0.0403 & 0.0385 & 0.0402 & 0.0552 & 0.0535 & 0.0550 \\
\hline
\end{tabular}

This table presents OLS regressions to examine the association between earnings comparability and stock price crash risk. We control for additional earnings attributes including conditional accounting conservatism and income smoothing. When estimating the coefficient standard errors, we correct for heteroskedasticity following White (1980) and use a firm-level clustering procedure that accounts for serial dependence across years for a given firm (Petersen, 2009). Two-tailed t-statistics are presented in the parentheses. *, **, and *** denote t-statistics are significant at 10, 5, and 1\% level. See Appendix A for variable definitions. documented by Khurana, Pereira, and Zhang (2018). These results justify the validity of our main findings.

\subsection{The Association Between Changes in Comparability and Changes in Crash Risk}

Since our primary empirical model based on level analysis is likely to be subject to an omitted correlated variable problem, we further conduct change analysis to control for such possible omitted correlated variables. Specifically, we examine whether the changes in comparability is associated with the changes in crash risk. Table 6 presents the results based on the change specifications, which are consistent with those presented in Table 3. The coefficient on $\triangle C o m p A c c t 4$ is significantly positive $(0.028, \mathrm{t}=2.07$ for $\triangle N C S K E W$, and 0.015 , 


\section{$\triangle 1$ Macrothink}

International Journal of Accounting and Financial Reporting

$\mathrm{t}=2.38$ for $\triangle D U V O L)$, supporting our interpretation that comparability predicts future crash risk.

\subsection{Alternative Measures of Comparability}

To assess the robustness of our main findings, we apply alternative measures of earnings comparability used by De Franco, Kothari, and Verdi (2011). Instead of constructing the firm-year measure of earnings comparability by taking the average value of the 4 firm $j$ with the highest comparability to firm i for fiscal year t (i.e., CompAcct4), we use either the average of the 10 firms with the highest comparability to firm $\mathrm{i}$ for fiscal year $\mathrm{t}$ (i.e., CompAcct10) or use the median firm-pair-year level of comparability for all firm $\mathrm{j}$ in the same industry as firm i for the fiscal year $\mathrm{t}$ (i.e., CompAcctInd). Table 7 reports the results based on the two alternative comparability measures, and the main finding that comparability is positively and significantly associated with future crash risk still hold.

Moreover, given Cheng, Hopwood, and McKeown's (1992) finding that the use of ranked accounting variables explains returns more than the raw measures, we also re-estimate our main model using fractional ranking of comparability measures and opacity measures within the industry and year, and report the results in Table 8. The findings are robust to these ranked variables. Interestingly, we find that the extent to which ranked comparability measures in explaining future crash risk is very similar to that of ranked opacity measure, supporting the significance of our findings.

\subsection{Subsample Analyses: The Role of Information Asymmetry}

To provide further evidence in support of our second hypothesis, we investigate the role of information asymmetry in affecting the positive association between earnings comparability and crash risk. We apply the measure of probability of informed trade (PIN) to proxy information asymmetry (Note 7). Specifically, PIN is based on the Venter and de Jongh (2006)'s extension of the EKO model (Easley, Kiefer, and O'Hara, 1997), measured over the annual period beginning 8 months before the firm's fiscal year end. We define firms with high (low) information asymmetry as those within the top (bottom) quintile of PIN, and conduct subsample analyses similar as those in Section 5.2. The results presented in Table 9 show that the positive association between comparability and crash risk only exists for firm with high PIN but disappears for firms with low PIN, consistent with our previous findings.

Table 6. Changes in comparability and changes in crash risk

\begin{tabular}{lll}
\hline VARIABLES & $\Delta$ NCSKEW $_{\mathrm{t}}$ & DDUVOL $_{\mathrm{t}}$ \\
\hline$\Delta$ CompAcct4 $_{\mathrm{t}-1}$ & $\mathbf{0 . 0 2 8}^{* *}$ & $\mathbf{0 . 0 1 5}^{* *}$ \\
& $\mathbf{( 2 . 0 7 )}$ & $\mathbf{( 2 . 3 8 )}$ \\
OPACITY $_{\mathrm{t}-1}$ & 0.042 & 0.019
\end{tabular}


$\Delta$ DTURN $_{\mathrm{t}-1}$

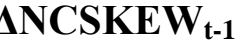

SIGMA $_{\text {t-1 }}$

$\Delta \mathbf{R O A}_{\mathrm{t}-1}$

Year Fixed Effect

Observations

Adj. R-squared
(1.08)

(1.07)

$0.027 * * *$

$0.011 * * *$

(5.05)

(4.65)

$-0.500 * * *$

$-0.216^{* * *}$

$(-92.09)$

$(-88.24)$

$-1.088^{* *}$

0.036

$(-2.14)$

(0.16)

0.020

$0.036^{*}$

(0.49)

$0.335^{* * *}$

$0.146^{* * * *}$

(13.67)

(13.21)

$0.026 * * *$

$0.013 * * *$

(11.01)

(12.14)

$-0.569 * * *$

$-0.253 * * *$

$(-7.90)$

$(-7.80)$

$0.396 * * *$

$0.271 * * *$

(3.87)

(5.86)

$-0.065$

0.001

$(-0.20)$

(0.01)

YES

YES

27,988

27,988

0.243 


\section{Mll Macrothink}

International Journal of Accounting and Financial Reporting ISSN 2162-3082

This table presents OLS regressions to examine the association between earnings comparability and stock price crash risk, using the change specifications. When estimating the coefficient standard errors, we correct for heteroskedasticity following White (1980) and use a firm-level clustering procedure that accounts for serial dependence across years for a given firm (Petersen, 2009). Two-tailed t-statistics are presented in the parentheses. *,**, and *** denote t-statistics are significant at 10,5, and 1\% level. See Appendix A for variable definitions.

Table 7. Alternative measures of earnings comparability

\begin{tabular}{|c|c|c|c|c|}
\hline VARIABLES & NCSKEW $_{t}$ & & DUVOL $_{t}$ & \\
\hline \multirow[t]{2}{*}{$\operatorname{CompAcct10}_{\mathrm{t}-1}$} & $0.027 * * *$ & & $0.013 * * *$ & \\
\hline & $(5.77)$ & & $(6.17)$ & \\
\hline \multirow{2}{*}{ CompAcctInd $_{t-1}$} & & $0.015 * * *$ & & $0.007 * * *$ \\
\hline & & $(5.22)$ & & $(5.87)$ \\
\hline \multirow[t]{2}{*}{ OPACITY $_{t-1}$} & $0.080 * * *$ & $0.082 * * *$ & $0.030 * * *$ & $0.031 * * *$ \\
\hline & $(3.89)$ & $(3.98)$ & $(3.29)$ & $(3.42)$ \\
\hline \multirow[t]{2}{*}{$\operatorname{DTURN}_{\mathrm{t}-1}$} & $0.030 * * *$ & $0.030 * * *$ & $0.015 * * *$ & $0.015^{* * *}$ \\
\hline & (5.29) & $(5.30)$ & $(6.13)$ & $(6.13)$ \\
\hline \multirow[t]{2}{*}{ NCSKEW $_{t-1}$} & $0.034 * * *$ & $0.034 * * *$ & $0.014 * * *$ & $0.014 * * *$ \\
\hline & $(5.86)$ & $(5.88)$ & $(5.62)$ & $(5.61)$ \\
\hline \multirow[t]{2}{*}{ SIGMA $_{t-1}$} & $2.308 * * *$ & $2.329 * * *$ & $0.355^{* *}$ & $0.373 * *$ \\
\hline & $(6.11)$ & $(6.14)$ & $(2.12)$ & $(2.22)$ \\
\hline \multirow[t]{2}{*}{$\mathbf{R E T}_{\mathrm{t}-1}$} & $0.206^{* * *}$ & $0.206^{* * *}$ & $0.072 * * *$ & $0.073 * * *$ \\
\hline & $(6.06)$ & $(6.08)$ & $(4.82)$ & $(4.85)$ \\
\hline \multirow[t]{2}{*}{$\operatorname{SIZE}_{t-1}$} & $0.049 * * *$ & $0.049 * * *$ & $0.024 * * *$ & $0.024 * * *$ \\
\hline & (16.98) & $(16.90)$ & (18.48) & $(18.40)$ \\
\hline
\end{tabular}




\begin{tabular}{|c|c|c|c|c|}
\hline \multirow[t]{2}{*}{$\mathbf{M B}_{\mathrm{t}-1}$} & $0.013 * * *$ & $0.014 * * *$ & $0.006 * * *$ & $0.006^{* * *} *$ \\
\hline & $(9.49)$ & (9.69) & $(10.04)$ & $(10.23)$ \\
\hline \multirow[t]{2}{*}{$\mathbf{L E V} \mathbf{t}_{\mathrm{t}-1}$} & $-0.169 * * *$ & $-0.171 * * *$ & $-0.084 * * *$ & $-0.085 * * *$ \\
\hline & $(-5.49)$ & $(-5.59)$ & $(-6.15)$ & $(-6.24)$ \\
\hline \multirow[t]{2}{*}{$\mathbf{R O A}_{t-1}$} & $0.435 * * *$ & $0.398 * * *$ & $0.275 * * *$ & $0.256^{* * *}$ \\
\hline & $(7.09)$ & $(6.35)$ & (10.16) & $(9.25)$ \\
\hline \multirow[t]{2}{*}{ Constant } & $-0.776^{* * *}$ & $-0.770 * * *$ & $-0.378 * * *$ & $-0.375^{* * *}$ \\
\hline & $(-3.34)$ & $(-3.32)$ & $(-3.68)$ & $(-3.65)$ \\
\hline Industry Fixed Effect & YES & YES & YES & YES \\
\hline Year Fixed Effect & YES & YES & YES & YES \\
\hline Observations & 33,696 & 33,696 & 33,696 & 33,696 \\
\hline Adj. R-squared & 0.0393 & 0.0392 & 0.0543 & 0.0542 \\
\hline
\end{tabular}

This table presents OLS regressions to examine the association between earnings comparability and stock price crash risk, using the alternative comparability measures from De Franco, Kothari, and Verdi (2011). When estimating the coefficient standard errors, we correct for heteroskedasticity following White (1980) and use a firm-level clustering procedure that accounts for serial dependence across years for a given firm (Petersen, 2009). Two-tailed t-statistics are presented in the parentheses. *, **, and *** denote t-statistics are significant at 10, 5, and $1 \%$ level. See Appendix A for variable definitions. 
Table 8. Robustness tests using ranked variables

\begin{tabular}{|c|c|c|c|c|c|c|}
\hline \multirow{2}{*}{ Rank_CompAcct $4_{t-1}$} & \multicolumn{3}{|c|}{ NCSKEW $_{t}$} & \multicolumn{3}{|c|}{ DUVOL $_{t}$} \\
\hline & $\begin{array}{c}0.073 * * \\
(4.34)\end{array}$ & & & $\begin{array}{c}0.035 * * \\
(4.71)\end{array}$ & & \\
\hline Rank_CompAcct10 & & $\begin{array}{c}0.076 * * * \\
(4.42)\end{array}$ & & & $\begin{array}{c}0.036 * * * \\
(4.77)\end{array}$ & \\
\hline Rank_CompAcetInd $d_{t-1}$ & & & $\begin{array}{c}0.071 * * * \\
(4.02)\end{array}$ & & & $\begin{array}{c}0.039 * * \\
(5.08)\end{array}$ \\
\hline Rank_OPACITY ${ }_{\mathrm{t}-1}$ & $\begin{array}{c}0.079 * * * * \\
(3.80)\end{array}$ & $\begin{array}{c}0.079 * * * * \\
(3.81)\end{array}$ & $\begin{array}{c}0.080^{* * * *} \\
(3.84)\end{array}$ & $\begin{array}{c}0.029 * * * \\
(3.20)\end{array}$ & $\begin{array}{c}0.029 * * * * \\
(3.21)\end{array}$ & $\begin{array}{c}0.031^{*} * * * \\
(3.33)\end{array}$ \\
\hline DTURN $_{\mathrm{t}-1}$ & $\begin{array}{c}0.031^{* * * *} \\
(5.38)\end{array}$ & $\begin{array}{c}0.031^{\text {* } k^{*} * *} \\
(5.37)\end{array}$ & $\begin{array}{c}0.030^{*} \text { *** } \\
(5.33)\end{array}$ & $\begin{array}{c}0.016^{* * * *} \\
(6.22)\end{array}$ & $\begin{array}{c}0.016^{* * * *} * \\
(6.21)\end{array}$ & $\begin{array}{c}0.016^{* * * *} \\
(6.15)\end{array}$ \\
\hline NCSKEW $_{\mathrm{t}-1}$ & $\begin{array}{c}0.034 * * * * \\
(5.95)\end{array}$ & $\begin{array}{c}0.034^{* * * *} * \\
(5.93)\end{array}$ & $\begin{array}{c}0.034^{*} * * * \\
(5.98)\end{array}$ & $\begin{array}{c}0.014^{* * * *} * \\
(5.71)\end{array}$ & $\begin{array}{c}0.014 * * * * \\
(5.69)\end{array}$ & $\begin{array}{c}0.014^{*} * * * \\
(5.70)\end{array}$ \\
\hline SIGMA $_{t-1}$ & $\begin{array}{l}2.296^{* * * *} \\
\quad(6.04)\end{array}$ & $\begin{array}{c}2.311^{* * * *} \\
(6.07)\end{array}$ & $\begin{array}{l}2.317^{\text {*k*k }} \\
(6.06)\end{array}$ & $\begin{array}{c}0.351^{* *} \\
(2.09)\end{array}$ & $\begin{array}{c}0.358^{* *} * \\
(2.12)\end{array}$ & $\begin{array}{c}0.386^{* * *} \\
(2.28)\end{array}$ \\
\hline $\mathbf{R E T}_{t-1}$ & $\begin{array}{c}0.209 * * * * \\
(6.14)\end{array}$ & $\begin{array}{c}0.209 * * * * \\
(6.16)\end{array}$ & $\begin{array}{c}0.210^{*} * * * \\
(6.16)\end{array}$ & $\begin{array}{c}0.074 * * * * \\
(4.92)\end{array}$ & $\begin{array}{c}0.074 * * * * \\
(4.94)\end{array}$ & $\begin{array}{c}0.075^{* * * *} \\
(5.01)\end{array}$ \\
\hline SIZE $_{t-1}$ & $\begin{array}{c}0.048^{* * * *} \cdot{ }^{2} \\
(16.33)\end{array}$ & $\begin{array}{c}0.048^{* * * * *} \\
(16.32)\end{array}$ & $\begin{array}{c}0.048^{* * * *} * \\
(16.32)\end{array}$ & $\begin{array}{c}0.023^{* * * *} \\
(17.78)\end{array}$ & $\begin{array}{c}0.023^{* * * *} \\
(17.76)\end{array}$ & $\begin{array}{c}0.023^{* * * *} \\
(17.69)\end{array}$ \\
\hline $\mathrm{MB}_{\mathrm{t}-1}$ & $\begin{array}{c}0.013^{* * *} * \\
(9.36)\end{array}$ & $\begin{array}{c}0.013^{*} * * * \\
(9.36)\end{array}$ & $\begin{array}{c}0.014^{* * * *} \\
(9.67)\end{array}$ & $\begin{array}{c}0.006^{* * * *} * \\
(9.88)\end{array}$ & $\begin{array}{c}0.006^{* * * *} * \\
(9.89)\end{array}$ & $\begin{array}{c}0.006^{* * * *} \\
(10.20)\end{array}$ \\
\hline $\operatorname{LEV}_{t-1}$ & $\begin{array}{c}-0.166^{* * * *} \cdot \\
(-5.36)\end{array}$ & $\begin{array}{c}-0.165^{\text {* }} \text { *** } \\
(-5.36)\end{array}$ & 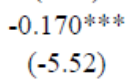 & 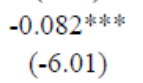 & $\begin{array}{c}-0.082 * * * \\
(-6.00)\end{array}$ & $\begin{array}{c}-0.083^{* * * *} \\
(-6.10)\end{array}$ \\
\hline $\mathbf{R O A}_{t-1}$ & $0.426^{* * * *}$ & $0.422^{* * * *}$ & $0.425^{* * * *}$ & $0.271^{* * *} *$ & $0.269^{* * * *}$ & $0.267^{* * *}$ \\
\hline Constant & $\begin{array}{c}(6.88) \\
-0.863^{* * *} * \\
(-3.71)\end{array}$ & $\begin{array}{c}(6.81) \\
-0.865^{* * * *} \\
(-3.72)\end{array}$ & $\begin{array}{c}(6.85) \\
-0.862^{* * *} * \\
(-3.70)\end{array}$ & $\begin{array}{c}(9.89) \\
-0.420^{*} \cdot k^{*} \\
(-4.08)\end{array}$ & $\begin{array}{c}(9.82) \\
-0.421^{* * * *} \\
(-4.09)\end{array}$ & $\begin{array}{c}(9.72) \\
-0.426^{* * *} k^{*} \\
(-4.14)\end{array}$ \\
\hline Industry Fixed Effect & YES & YES & YES & YES & YES & YES \\
\hline Year Fixed Effect & YES & YES & YES & YES & YES & YES \\
\hline Observations & 33,696 & 33,696 & 33,696 & 33,696 & 33,696 & 33,696 \\
\hline Adj. R-squared & 0.0389 & 0.0390 & 0.0389 & 0.0539 & 0.0539 & 0.0540 \\
\hline
\end{tabular}

This table presents OLS regressions to examine the association between earnings comparability and stock price crash risk. We use the fractional ranking of the measures of comparability and financial reporting opacity measure within its industry-year (two-digit SIC). When estimating the coefficient standard errors, we correct for heteroskedasticity following White (1980) and use a firm-level clustering procedure that accounts for serial dependence across years for a given firm (Petersen, 2009). Two-tailed t-statistics are presented in the parentheses. *, **, and *** denote t-statistics are significant at 10,5 , and $1 \%$ level. See Appendix A for variable definitions.

Table 9. Subsample Analyses - The Effect of Information Asymmetry

\begin{tabular}{lllll}
\hline & NCSKEW $_{\mathbf{t}}$ & & DUVOL $_{\mathbf{t}}$ & \\
VARIABLES & High PIN & Low PIN & High PIN & Low PIN \\
\hline CompAcct4 $_{\mathrm{t}-1}$ & $\mathbf{0 . 0 4 4 * * *}$ & 0.006 & $\mathbf{0 . 0 1 8}^{* * * *}$ & 0.007 \\
& $\mathbf{( 3 . 2 1 )}$ & $(0.33)$ & $\mathbf{( 3 . 0 2 )}$ & $(0.86)$
\end{tabular}


OPACITY $_{t-1}$

$0.110^{* *}$

0.080

$0.050 * *$

0.034

(2.28)

$(1.59)$

(2.39)

$(1.50)$

DTURN $_{\text {t-1 }}$

0.031

0.009

$0.015^{*}$

0.005

$(1.50)$

$(0.82)$

(1.66)

(1.04)

NCSKEW $_{\text {t-1 }}$

0.010

0.017

0.004

0.006

(0.70)

(1.22)

(0.60)

(1.00)

SIGMA $_{\text {t-1 }}$

1.610

$6.653^{* * *}$

$-0.119$

$2.172 * * *$

(4.58)

$(-0.23)$

(3.33)

RET $_{\text {t-1 }}$

0.136

$0.753^{* * *}$

0.018

$0.294^{* * *}$

(1.09)

(4.46)

(0.33)

(3.88)

SIZE $_{\text {t-1 }}$

$0.062 * * *$

$0.027 * * *$

$0.029 * * *$

$0.014 * * *$

(3.50)

(6.23)

$\mathbf{M B}_{\mathrm{t}-1}$

$0.009 * *$

$0.010^{* * *}$

$0.006 * * *$

$0.004 * * *$

(2.09)

(3.26)

(2.96)

(3.20)

$\mathrm{LEV}_{\text {t-1 }}$

$-0.145^{*}$

$-0.222 * * *$

$-0.056^{*}$

$-0.118^{* * *}$

$(-1.90)$

$(-2.75)$

$(-1.69)$

$(-3.26)$

$\operatorname{ROA}_{t-1}$

0.037

$0.509 * * *$

0.103

$0.307 * * *$

$(0.23)$

(3.26)

(1.47)

(4.37)

Constant

$-0.442$

0.584

$-0.189$

$-0.022$

$(-0.53)$

(1.02)

$(-0.52)$

$(-0.09)$

Industry Fixed Effect

YES

YES

YES

\section{YES}

Year Fixed Effect

YES

YES

YES

YES

Observations

5,773

5,720

5,773

5,720

Adj. R-squared

0.0237

0.0364

0.0329

0.0457 


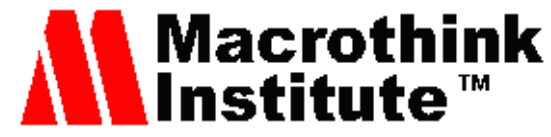

International Journal of Accounting and Financial Reporting

ISSN 2162-3082

2018, Vol. 8, No. 3

This table presents OLS regressions to examine the association between earnings comparability and stock price crash risk for firms with high probability of informed trading (PIN) and those with low PIN. When estimating the coefficient standard errors, we correct for heteroskedasticity following White (1980) and use a firm-level clustering procedure that accounts for serial dependence across years for a given firm (Petersen, 2009). Two-tailed t-statistics are presented in the parentheses. *, **, and *** denote t-statistics are significant at 10, 5, and $1 \%$ level. See Appendix A for variable definitions.

\section{Conclusions}

This study examines the association between earnings comparability and firm-specific stock price crash risk. We document a positive association between comparability and future stock price crash risk. This finding is consistent with the notion that corporate managers do not have much incentive to release firm-specific information (especially bad news), as long as their firms' financial statements are comparable to those of the industry peers. We further show that the positive association between earnings comparability and future crash risk is diminished for firms with strong external monitoring and firms with low information asymmetry.

Our study contributes to the literature on financial reporting comparability and its implications on firms and information users. By providing in-depth analysis of the association between earnings comparability and crash risk, this paper furthers our understanding about the capital market outcomes of earnings comparability. One important implication of our documented positive comparability-crash risk association is that earnings comparability does not always lead to favorable capital market outcomes. We also extend the growing literature on the firm-specific predictors of future stock price crash risk by highlighting the incremental effect of earnings comparability in predicting future crash risk over certain common earnings attributes, such as financial reporting opacity, conditional conservatism, income smoothing.

\section{Acknowledgement}

Data Availability: Data used are from public sources identified in this paper.

\section{References}

Alford, A. W. (1992). The effect of the set of comparable firms on the accuracy of the price earnings valuation method. Journal of Accounting Research, 30, 94-108.

Barth, M. E., Landsman, W. R, Lang, M., \& Williams, C. (2012). Are IFRS-based and US GAAP-based accounting amounts comparable?. Journal of Accounting and Economics, 54, 68-93.

Basu, S. (1997). The conservatism principle and the asymmetric timeliness of earnings. Journal of Accounting and Economics, 24, 3-37.

Becker, C. L., Defond, M. L., Jiambalvo, J., \& Subramanyam, K. R. (1998). The effect of audit quality on earnings management. Contemporary Accounting Research, 15, 1-24. 


\section{$\triangle 1$ Macrothink}

International Journal of Accounting and Financial Reporting

ISSN 2162-3082

2018, Vol. 8, No. 3

Ben-Nasr, H., \& Ghouma, H. (2018). Employee welfare and stock price crash risk. Journal of Corporate Finance, 48, 700-725.

Bhargava, R., Faircloth, S., \& Zeng, H. (2017). Takeover protection and stock price crash risk: Evidence from state antitakeover laws. Journal of Business Research, 70, 177-184.

Bhojraj, S., \& Lee, C. M. C (2002). Who is my peer? A valuation-based approach to the selection of comparable firms. Journal of Accounting Research, 40, 407-439.

Bradshaw, M. T., Miller, G. S., \& Serafeim, G. (2009). Accounting method heterogeneity and analysts' forecast. Working Paper. Boston College, University of Michigan, and Harvard University.

Brochet, F., Jagolinzer, A. D., \& Riedl, E. J. (2013). Mandatory IFRS adoption and financial statement comparability. Contemporary Accounting Research, 30, 1373-1400.

Brown, S., \& Hillegeist, S. A. (2007). How disclosure quality affects the level of information asymmetry. Review of Accounting Studies, 12, 443-477.

Bushee, B. J. (1998). The influence of institutional investors in myopic R\&D investment behavior. The Accounting Review, 73, 305.

Callen, J. L., \& Fang, X. (2013). Institutional investor stability and crash risk: Monitoring versus short-termism?. Journal of Banking \& Finance, 37, 3047-3063.

Callen, J. L., \& Fang, X. (2015a). Religion and stock price crash risk. Journal of Financial and Quantitative Analysis, 50(2), 169-195.

Callen, J. L., \& Fang, X. (2015b). Short interest and stock price crash risk. Journal of Banking \& Finance, 60, 181-194.

Campbell, J. L., \& Yeung, P. E. (2017). Earnings comparability, accounting similarities, and stock returns: Evidence from peer firms' earnings restatement. Journal of Accounting, Auditing, \& Finance, 32(4), 480-509.

Chang, X., Chen, Y., \& Zolotoy, L. (2017). Stock liquidity and stock price crash risk. Journal of Financial and Quantitative Analysis, 52(4), 1605-1637.

Chen, C. W., Collins, D. W., Kravet, T. D., \& Mergenthaler, R. D. (2018). Financial statement comparability and the efficiency of acquisition decisions. Contemporary Accounting Research, 35(1), 164-202.

Chen, J., Hong, H., \& Stein, J. C. (2001). Forecasting crashes: Trading volume, past returns, and conditional skewness in stock prices. Journal of Financial Economics, 61, 345-381.

Chen, J., Tong, J. Y., Wang, W., \& Zhang, F. (2017). The economic consequences of labor unitization: Evidence from stock price crash risk. Journal of Business Ethics. Forthcoming.

Cheng, C. S. A., \& McNamara, R. (2000). The valuation accuracy of the price-earnings and price-book benchmark valuation methods'. Review of Quantitative Finance and Accounting, $15,349-70$. 


\section{Macrothink}

International Journal of Accounting and Financial Reporting ISSN 2162-3082

Cheng, C. S. A., Hopwood, W. S., \& McKeown, J. C. (1992). Nonlinearity and specification problems in unexpected earnings response regression-model. The Accounting Review, 67, 579-598.

Cheng, J. C., \& Wu. R. S. (2018). Internal capital market efficiency and the diversification discount: The role of financial statement comparability. Journal of Business Finance \& Accounting, 45, 572-603.

Choi, J. H., Choi, S., Myers L.A., \& Ziebart, D. (2017). Financial statement comparability and the ability of current stock returns to reflect the information in future earnings. Working Paper. Seoul National University, University of Arkansas, and University of Kentucky.

Dang, T. L., Faff, R. W., Luong, H., \& Nguyen, L. (2018). Individualistic cultures and crash risk. European Financial Management, Forthcoming.

Dang, V. A., Lee, E., Liu, Y., \& Zeng, C. (2018). Corporate debt maturity and stock price crash risk. European Financial Management, 24(3), 451-484.

De Franco, G., Kothari, S. P., \& Verdi, R. S. (2011). The benefits of financial statement comparability. Journal of Accounting Research, 49, 895-931.

DeFond, M. L., Hu, X., Hung, M., \& Li, S. (2011). The impact of mandatory IFRS adoption on foreign mutual fund ownership: The role of comparability. Journal of Accounting and Economics, 51, 240-258.

DeFond, M. L., Hung, M., Li, S., \& Li, Y. (2014). Does mandatory IFRS adoption affect crash risk?. The Accounting Review, 90, 265-299.

DeFond, M., \& Jiambalvo, J. (1991). Incidence and circumstances of accounting errors. The Accounting Review, 66, 643.

Dimson, E. (1979). Risk measurement when shares are subject to infrequent trading. Journal of Financial Economics, 7, 197-226.

Easley, D., Kiefer, N. M., \& O’Hara, M. (1997). One day in the life of a very common stock. Review of Financial Studies, 10, 805-835.

Fang, X., Li, Y., Xin, B., \& Zhang, W. (2016). Financial statement comparability and debt contracting: Evidence from the syndicated loan market. Accounting Horizon, 30(2), 277-303.

Financial Accounting Standards Board (FASB). (1980). Statement of Financial Accounting Concept No.2: Qualitative Characteristics of Accounting Information.

Francis, J. R., Maydew, E. L., \& Sparks, H. C. (1999). The role of Big 6 auditors in the credible reporting of accruals. Auditing: A Journal of Practice \& Theory, 18(2), 17-34.

Francis, J., LaFond, R., Olsson, P. M., \& Schipper, K. (2004). Costs of equity and earnings attributes. The Accounting Review, 79, 967-1010.

Gong, G., Li, L., \& Zhou, L. (2013). Earnings non-synchronicity and voluntary disclosure. Contemporary Accounting Research, 30, 1560-1589. 


\section{Mll Macrothink}

International Journal of Accounting and Financial Reporting

ISSN 2162-3082 2018, Vol. 8, No. 3

Habib, A., Hassan, M. M., \& Al-Hadi, A. (2017). Financial statement comparability and corporate cash holdings. Journal of Contemporary Accounting \& Economics, 13(3), 304-321.

Habib, A., Hassan, M. M., \& Al-Hadi, A. (2018). Financial statement comparability and idiosyncratic return volatility. International Review of Finance, Forthcoming.

Hong, H. A., Kim, J. B., \& Welker, M. (2017). Divergence of cash flow and voting rights, opacity, and stock price crash risk: International evidence. Journal of Accounting Research, 55(5), 1167-1212.

Horton, J., Serafeim, G., \& Serafeim, I. (2013). Does mandatory IFRS adoption improve the information environment?. Contemporary Accounting Research, 30, 388-423.

Hribar, P., \& Collins, D. W. (2002). Errors in estimating accruals: Implications for empirical research. Journal of Accounting Research, 40, 105-134.

Hutton, A. P., Marcus, A. J., \& Tehranian, H. (2009). Opaque financial reports, ${ }^{2}$, and crash risk. Journal of Financial Economics, 94, 67-86.

Imhof, M. J., Seavey, S. E., Smith, D. B. (2017). Comparability and cost of equity capital. Accounting Horizon, 31(2), 125-138.

Jensen, M. C., \& Meckling, W. H. (1976). Theory of the firm: Managerial behavior, agency costs and ownership structure. Journal of Financial Economics, 3, 305-360.

Jin, L., \& Myers, S. C. (2006). $\mathrm{R}^{2}$ around the world: New theory and new tests. Journal of Financial Economics, 79, 257-292.

Jones, J. J. (1991). Earnings management during import relief investigations. Journal of Accounting Research, 29, 193-228.

Khan, M., \& Watts, R. L. (2009). Estimation and empirical properties of a firm-year measure of accounting conservatism. Journal of Accounting \& Economics, 48, 132-150.

Khurana, I. K., Pereira, R., \& Zhang, E. (2018). Is real earnings smoothing harmful? Evidence from firm-specific stock price crash risk. Contemporary Accounting Research, $35(1), 558-587$.

Kim, J. B., \& Zhang, L. (2016). Accounting conservatism and stock price crash risk: Firm-level evidence. Contemporary Accounting Research, 33(1), 412-441.

Kim, J. B., Li, L., Lu, L. Y., \& Yu, Y. (2016). Financial statement comparability and expected crash risk. Journal of Accounting and Economics, 61, 294-312.

Kim, J. B., Li, Y., \& Zhang, L. (2001a). CFOs versus CEOs: Equity incentives and crashes. Journal of Financial Economics, 101, 713-730.

Kim, J. B., Li, Y., \& Zhang, L. (2011b). Corporate tax avoidance and stock price crash risk: Firm-level analysis. Journal of Financial Economics, 100, 639-662. 


\section{MlMacrothink}

International Journal of Accounting and Financial Reporting

ISSN 2162-3082

2018, Vol. 8, No. 3

Kim, S., Kraft, P., \& Ryan, S. G. (2013). Financial statement comparability and credit risk. Review of Accounting Studies, 18, 783-823.

Kim, Y., \& Li, S. (2010). Mandatory IFRS adoption and intra-industry information transfers. Working Paper. Santa Clara University

Kim, Y., Li, H., \& Li, S. (2014). Corporate social responsibility and stock price crash risk. Journal of Banking \& Finance, 43, 1-13.

Kubick, T. R., \& Lockhart, G. B. (2016). Proximity to the SEC and stock price crash risk. Financial Management, 45, 341-367.

Lee, M. G., Kang, M., Lee, H. Y., \& Park J. C. (2016). Related-party transactions and financial statement comparability: Evidence from South Korea. Asia-Pacific Journal of Accounting \& Economics, 23, 224-252.

Lipe, M. G., \& Salterio, S. E. (2000). The balanced scorecard: judgmental effects of common and unique performance measures. The Accounting Review, 75, 283-98.

Neel, M. (2017). Accounting comparability and economic outcomes of mandatory IFRS adoption. Contemporary Accounting Research, 34(1), 658-690.

Ozkan, N., Singer, Z., \& You, H. (2012). Mandatory IFRS adoption and the contractual usefulness of accounting information in executive compensation. Journal of Accounting Research, 50, 1077-1107.

Petersen, M. A. (2009). Estimating standard errors in finance panel data sets: Comparing approaches. The Review of Financial Studies, 22, 435-480.

Peterson, K., Schmardebeck, R., \& Wilks, J. (2012). Accounting comparability and earnings attributes. Working Paper. University of Oregon, University of Arkansas, and Brigham Young University.

Scholes, M., \& Williams, J. (1997). Estimating betas from nonsynchronous data. Journal of Financial Economics, 5, 309-327.

Sohn, B. C. (2016). The effect of accounting comparability on the accrual-based and real earnings management. Journal of Accounting and Public Policy, 35(5), 513-539.

Venter, J. H., \&. de Jongh, D. C. (2006). Extending the EKOP model to estimate the probability of informed trading. Studies in Economics and Econometrics, 2, 25-39.

Wang, C. (2014). Accounting standards harmonization and financial statement comparability: Evidence from transnational information transfer. Journal of Accounting Research, 52, 955-992.

White, H. (1980). A heteroskedasticity-consistent covariance matrix estimator and a direct test for heteroscedasticity. Econometrica, 48(4), 817-838.

Yu, F. (2008). Analyst coverage and earnings management. Journal of Financial Economics, $88,245-271$. 


\section{1l Macrothink}

International Journal of Accounting and Financial Reporting

ISSN 2162-3082

2018, Vol. 8, No. 3

\section{Notes}

Note 1. The third moment of stock return distribution (i.e., skewness) is distinct from other return distributions commonly investigated in the prior studies, such as the first moment (i.e., the mean) capturing the stock average performance, and the second moment (i.e., the variance) capturing the firm risk.

Note 2. Consistent with this view, Gong, Li, and Zhou (2013) provide evidence that managers' propensity to provide voluntary disclosures in the form of management earnings forecast is higher when the firm's earnings have low covariance with those of its industry peers (i.e., firm with high earnings non-synchronicity).

Note 3. We apply measures of comparability developed by De Franco, Kothari, and Verdi (2011) in our main analyses.

Note 4. Kim, Li, Lu, and Yu (2016) only use the ex ante proxies for crash risk and do not provide any evidence or discussion on ex post proxies of crash risk, which are the most commonly used proxies in the literature.

Note 5. Other studies focus on the selection of comparable firms to examine valuation methods. For instance, Bhojraj and Lee (2002) use stock return co-movement as a way to measure economic relatedness among firms as a way to select comparable firms. Alford (1992) selects comparable firms on the basis of industry, size, and earnings growth. Cheng and McNamara (2000) evaluate the P/E, P/B benchmark valuation method and a combined $\mathrm{P} / \mathrm{E}-\mathrm{P} / \mathrm{B}$ valuation method.

Note 6. By using firm i's return in its predictions, we hold the economic events constant.

Note 7. We greatly thank Dr. Stephen Brown in generously sharing his PIN dataset on his website.

\section{Appendix A. Variables Definitions}

Crash Risk Measures

NCSKEW $\quad=$ The negative skewness of firm-specific weekly returns, calculated by taking the negative value of the third moment of firm-specific weekly returns during the same fiscal year, scaled by the standard deviation of firm specific returns raised to the third power, as described in detail in Section 3.1

DUVOL = The natural logarithm of the standard deviation ratio of down weeks to that of up weeks, as described in detail in Section 3.1. 


\section{Macrothink \\ International Journal of Accounting and Financial Reporting \\ ISSN 2162-3082 \\ 2018, Vol. 8, No. 3}

Comparability and Other Earnings Attributes Measures

CompAcct4 = The average of the four highest values of firm-pair-year level of comparability measure for firm i, as described in detail in Section 3.2

CompAcct10 = The average of the ten highest values of firm-pair-year level of comparability measure for firm i, as described in detail in Section 3.2

CompAcctInd $=$ The median of values of firm-pair-year level of comparability measure for all firms in firm i's industry, as described in detail in Section 3.2.

OPACITY = The previous three years' moving sum of the absolute value of discretionary accruals, measured using the Modified Jones (1991) Model, as described in detail in Section 3.3.

CSCORE = Conditional conservatism measure developed by Khan and Watts (2009), as described in detail in Section 6.1

SMOOTH = Income Smoothing measure by Francis, LaFond, Olsson, and Schipper (2004), calculated as the volatility of income with respect to the volatility of cash flows over the most recent five-year rolling window

Control Variables

DTURN $=$ The average monthly share turnover minus the average monthly share turnover over the previous fiscal year period, where monthly share turnover is calculated as the monthly trading volume divided by the total number of shares outstanding during the month

SIGMA = The standard deviation of firm-specific weekly returns over the fiscal year period

RET = The mean of firm-specific weekly returns over the fiscal year period, times 10

SIZE $\quad=$ The natural logarithm of the market value of equity

$M B=$ Market-to-book ratio, measured as the market value of equity divided by book value of equity

LEV $\quad=$ The total long-term debts divided by total assets

$R O A=$ Income before extraordinary items divided by lagged total assets 
Proxies for External Monitoring and Information Asymmetry

NANAL $=$ Analyst coverage, measured as the natural logarithm of one plus the number of analysts following a firm at a specific year

IO = Institutional ownership, measured as the natural logarithm of one plus the ratio of institutional holding to total shares outstanding for a firm at a specific year

BIG4 = An indicator variable that takes value of one if a firm is audited by a Big 4 auditor at a specific year, and zero otherwise

PIN = The probability of informed trading, based on the Venter and de Jongh (2006)'s extension of the EKO model (Easley, Kiefer, and O'Hara, 1997), measured over the annual period beginning 8 months before the firm's fiscal year end

\section{Copyright Disclaimer}

Copyright for this article is retained by the author(s), with first publication rights granted to the journal.

This is an open-access article distributed under the terms and conditions of the Creative Commons Attribution license (http://creativecommons.org/licenses/by/4.0/) 